\title{
The development and application of the alteration strength index equation
}

\author{
L.D. Wyering a,*, M.C. Villeneuve ${ }^{\text {a }}$, I.C. Wallis ${ }^{\text {b }}$, P.A. Siratovich ${ }^{\text {a }}$, B.M. Kennedy ${ }^{\text {a }}$, D.M. Gravley ${ }^{\text {a }}$ \\ a Department of Geological Sciences, University of Canterbury, P O Box 4800, Christchurch 8140, New Zealand \\ b Mighty River Power, 283 Vaughan Road, P O Box 245, Rotorua 3040, New Zealand
}

\section{A R T I C L E I N F O}

\section{Article history:}

Received 20 April 2015

Received in revised form 30 July 2015

Accepted 10 October 2015

Available online 22 October 2015

\section{Keywords:}

Empirical relationships

Uniaxial compressive strength

Alteration strength index (ASI)

Porosity

Microstructural

\begin{abstract}
A B S T R A C T
We have developed an alteration strength index (ASI) equation to address the effect of hydrothermal alteration on mechanical rock properties. This equation can be used to estimate a range of rock strengths, comparable to uniaxial compressive strength (UCS), based on rapid analysis of mineralogy and microstructure. We used rock samples from three geothermal fields in the Taupo Volcanic Zone (TVZ) to represent a range of alteration types. These are sedimentary, intrusive and extrusive rocks, typical of geothermal systems, from shallow and deep boreholes ( 72 measured Depth $(\mathrm{mD})$ to $3280 \mathrm{mD}$ ). The parameters used in ASI were selected based on literature relating these aspects of mineralogy and microstructure to rock strength. The parameters in ASI define the geological characteristics of the rock, such as proportions of primary and secondary mineralogy, individual mineral hardness, porosity and fracture number. We calibrated the ASI against measured UCS for our samples from the TVZ to produce a strong correlation ( $\mathrm{R}^{2}$ of 0.86 ), and from this correlation we were able to derive an equation to convert ASI to UCS. Because the ASI-UCS relationship is based on an empirical fit, the UCS value that is obtained from conversion of the ASI includes an error of $7 \mathrm{MPa}$ for the 50th percentile and $25 \mathrm{MPa}$ for the 90th percentile with a mean error of $11 \mathrm{MPa}$. A sensitivity analysis showed that the mineralogy parameter is the dominant characteristic in this equation, and the ASI equation using only mineralogy can be used to provide an estimated UCS range, although the error (or uncertainty) becomes greater. This provides the ability to estimate strength even when either fracture or porosity information are not available, for example in the case of logging drill cuttings. This research has also allowed us to provide ranges of rock strengths based solely on the alteration zones, mineralogy, and depth of lithologies found in a typical geothermal field that can be used to update conceptual models of geothermal fields.
\end{abstract}

(c) 2015 Elsevier B.V. All rights reserved.

\section{Introduction}

Rock strength is necessary for geothermal reservoir development, management and prospect evaluation because it controls rock behaviour during drilling, stimulation and resource extraction. Tools that predict rock properties are critical because there are usually limited or no borehole-based rock property data (Gunsallus and Kulhawy, 1984; Edlmann et al., 1998; Ameen and Smart, 2009). Relationships between strength and porosity, density or mineralogy for a specific rock formation have been widely developed based on laboratory tests on rock core from a given field or lithology (Chang et al., 2006; Tamrakar et al., 2007; Rigopoulos et al., 2010; Singh et al., 2012; Karakul and Ulusay, 2013). These relationships, however, were developed using mainly sedimentary, granitic and metamorphic rock samples and cannot be applied ubiquitously to all lithologies, especially hydrothermally altered volcanic rocks. Only recently have studies investigated the physical and mechanical properties of volcanic rocks (Ladygin et al., 2000; Frolova et al.,

\footnotetext{
* Corresponding author at: Department of Geological Sciences, University of Canterbury, Private Bag 4800, Christchurch 8140, New Zealand.

E-mail address: latasha.wyering@pg.canterbury.ac.nz (L.D. Wyering).
}

2005; Vinciquerra et al., 2005; Smith et al., 2009; Frolova et al., 2010; Nara et al., 2011; Pola et al., 2012; Heap et al., 2014a; Pola et al., 2014; Wyering et al., 2014; Heap et al., 2015) with reference to how different rock properties impact the strength of the material.

Recovering core to test is expensive and, owing to the fractures in the rocks, recovery can be poor leading to only a limited number of samples tested in a given geothermal field. Therefore, many researchers and industry practitioners apply empirical strength relations to borehole geophysics data or limited laboratory data (Edlmann et al., 1998; Koncagül and Santi, 1999; Dinçer et al., 2004; Entwisle et al., 2005; Çobanoğlu and Çelik, 2008; Binal, 2009). Chang et al. (2006) reviewed thirty-two empirical relationships for sedimentary rocks where physical rock properties were derived from borehole geophysics. Their review made clear that a few of the empirical relationships appeared to work fairly well for some subsets of the rocks studied. Wyering et al., 2012 assessed the applicability of selected empirical equations for predicting uniaxial compressive strength (UCS) for geothermally altered lithologies and found that the correlations between predicted UCS and measured UCS were poor. The downfall of these empirical relationships is that they are only applicable to the particular lithologies being studied, and do not necessarily correlate for all rock types, especially silicic 
volcanic rocks affected by secondary mineralisation. Whilst the equations presented in Chang et al. (2006) may be useful to a practitioner in the geothermal industry as a first order approximation, they are focused on sedimentary rocks with no high-temperature secondary mineralisation and therefore have limited utility (Yagiz, 2009).

Research has shown that several rock properties (mineral hardness, secondary minerals, microstructural damage that includes the presence of microfractures and pores) can influence the predicted rock strength of material (Tuğrul and Zarif, 1999; Ameen and Smart, 2009; Rigopoulos et al., 2010; Coggan et al., 2013; Heap et al., 2014a). Several petrographic and weathering indices related to chemical, petrological and mechanical properties, have been suggested to identify the impact of alteration on rock properties in different lithologies (Ulusay et al., 1994; Tamrakar et al., 2007; Ceryan et al., 2008; Yildiz et al., 2010; Pola et al., 2012, 2014).

This paper describes the development of a strength prediction equation that can be used to calculate a strength range comparable to UCS using descriptions of hydrothermal alteration, secondary mineralisation, porosity and bulk rock structural damage. The core samples used are sourced from the Ngatamariki, Rotokawa and Kawerau geothermal fields from the Taupo Volcanic Zone (TVZ), New Zealand, allowing the equation to be adapted for geothermal fields located in the TVZ. It encompasses a variety of lithologies that are found in the TVZ and the differing geothermal environments they are exposed to. The equation could be used in other geothermal systems worldwide with similar geothermal conditions or adapted easily to suit. We will show that development of this equation has improved understanding of how alteration mineralogy and physical properties control rock strength. We will demonstrate how a variant of the equation could be used in the field to optimize drilling of geothermal reservoirs through improved drill bit selection.

\section{Geothermal setting}

The active Taupo Volcanic Zone (TVZ) is located at the southern end of the Tonga Kermadec arc in the central North Island of New Zealand, in a $300 \mathrm{~km}$ long ( $200 \mathrm{~km}$ on land) and $60 \mathrm{~km}$ wide belt, defined by caldera structural boundaries, volcanic vent positions and geothermal systems (Fig. 1: Cole, 1990; Wilson et al., 1995). The $>20$ geothermal systems in the TVZ, totaling 4500 MW thermal output (Bibby et al., 1995), are related to magmatic heat generated at depth and shallow crustal structure that provides the permeability necessary for convective transport of hydrothermal fluids (Rowland and Sibson, 2004; Rowland and Simmons, 2012). These circulating fluids become rich in dissolved minerals, as they percolate through the stratigraphy (Henneberger and Browne, 1988) and precipitate minerals in the reservoir rocks producing the secondary mineralisation that are observed when the rocks are drilled and brought to the surface (Goff and Janik, 2000). The rock types we used in this study (described in detail in Wyering et al., 2014) were sourced from shallow formations - Rhyolitic ignimbrite, Rhyolitic lava, and Siltstone/Sandstone - and from deep formations Rhyolitic ignimbrite, Andesite Lava/Breccia and Tonalite intrusive from numerous geothermal fields in the TVZ.

\section{Data source}

All of the data used in this study are sourced from Wyering et al. (2014). They characterized the physical and mechanical properties of lithologies from the Ngatamariki, Rotokawa and Kawerau geothermal fields (Fig. 1), using non-destructive and destructive methods to determine porosity, density, ultrasonic wave velocities and uniaxial compressive strength (UCS). The samples were cored to a mean diameter of $39.6 \mathrm{~mm}$ and were cut and ground to within the length to diameter ratio of $2: 1$. Their study examined thin sections using a polarized light microscope, that utilized plane polarized light (PPL) and crosspolarized light (CPL) to identify primary and secondary minerals (that includes but is not limited to clays, quartz, epidote, chlorite, albite and pyrite), microfractures and bulk rock fractures in the lithologies. Although Wyering et al. (2014) did mention the textures of the samples, they were not used in this study because the samples were moderately to intensely altered. The textures within the samples were completely replaced and difficult to distinguish, reducing the ability to use the data.

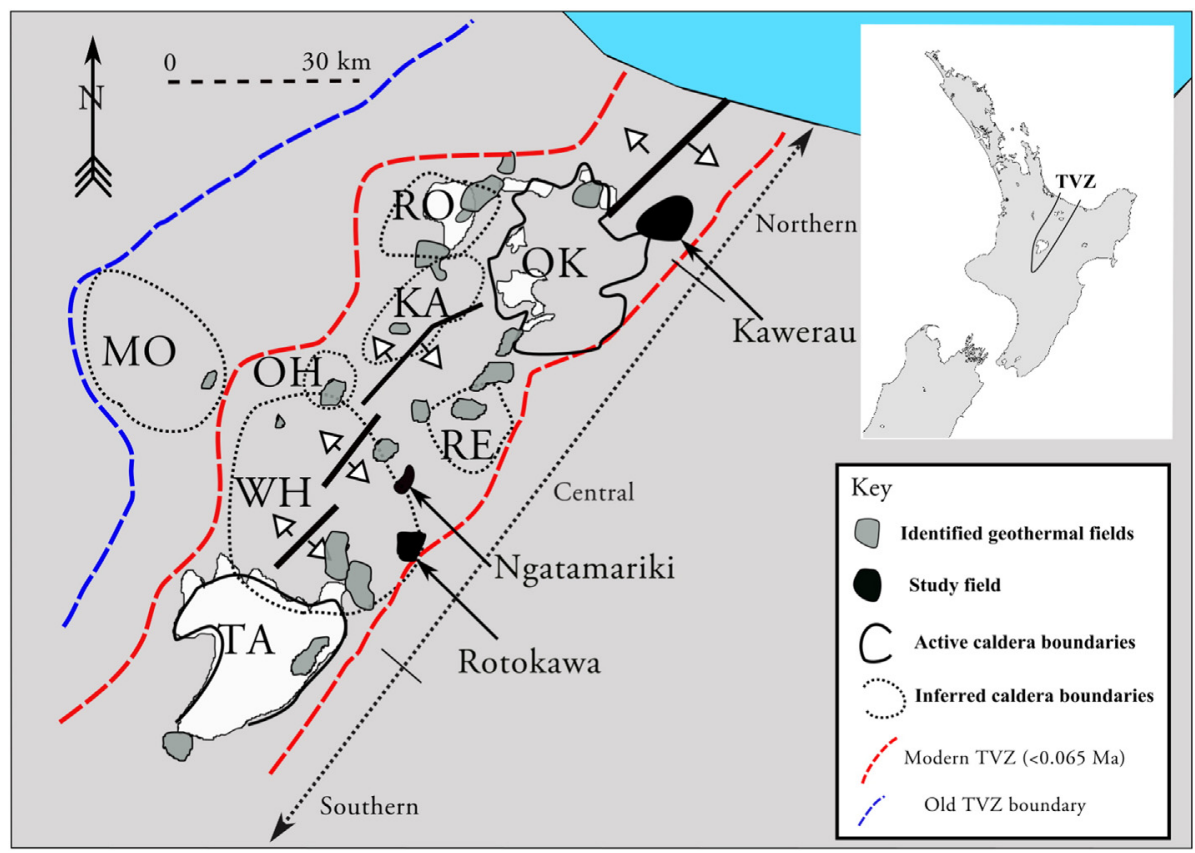

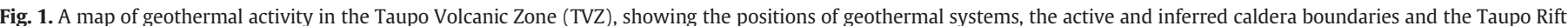

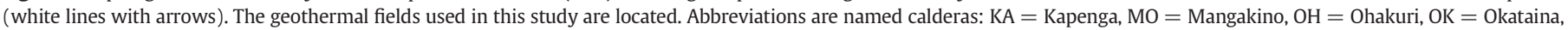

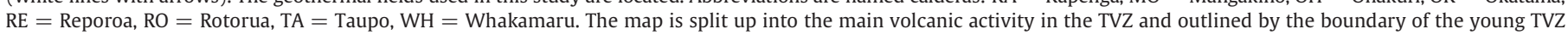
$(<0.34 \mathrm{Ma})$ (Adapted from Wilson et al., 1995; Bibby et al., 1995; Rowland and Sibson, 2004; Kissling and Weir, 2005; Rowland and Simmons, 2012). 
Table 1

The semi-quantitative categories for the primary minerals and the percentages representing the categories.

\begin{tabular}{lc}
\hline Category & Representative percentage \\
\hline Abundant (A) & 50 \\
Common (C) & 25 \\
Minor (M) & 10 \\
Rare (R) & 5 \\
\hline
\end{tabular}

For this study we used their connected porosity, ( $\Phi$ herein referred to as porosity), UCS results, and thin section analysis of the lithologies. Wyering et al. (2014) used the suggested method from the International Society of Rock Mechanics (ISRM) (Ulusay and Hudson, 2007a) to determine the porosity (as volume \%) and density of the hydrothermally altered samples using cylindrical cores. They did not measure total porosity (sum of connected and closed porosity) because its measurement requires grinding the sample into a powder, which is incompatible with further tests, such as UCS. UCS testing was completed using the ISRM suggested methods (Ulusay and Hudson, 2007b) and the American Society for Testing and Materials (ATSM, 2010). The samples were tested using a Technotest $3000 \mathrm{kN}$, servo-controlled loading frame and loaded at a constant stress rate (between $0.02 \mathrm{kN} / \mathrm{s}$ to $0.500 \mathrm{kN} / \mathrm{s}$ ) to ensure failure occurred within 5-10 min. Tokyo Sokki Kenkyujo Co. Ltd. (TML) $20 \mathrm{~mm}$ strain gauges with a factor of 2.12 were glued to the samples; two axial and two radial. The samples were tested at ambient laboratory temperature and humidity conditions.

\section{Proposed equation - alteration strength index (ASI)}

The alteration strength index equation (ASI), developed in this study, is given in Eq. (1). In this section, we introduce the equation and explain the meaning of each of the parameters, and how they relate to each other. The purpose of the equation is to estimate of rock strength based on physical and mineralogical properties, which can be undertaken rapidly in the field. This method does not require establishing the primary lithology of the material to estimate rock strength, but rather focuses on the physical characteristics of the rocks as they are found. We selected the parameters that make up the equation were based on published research that shows which key parameters affect the strength of both hydrothermally altered and unaltered rocks.

$\mathrm{ASI}=\left(\mathrm{P}_{\mathrm{m}} \times(1-\mathrm{AI})+\mathrm{S}_{\mathrm{m}} \times \mathrm{AI}\right) \times\left(\Phi^{-0.03}\right) \times\left(1-\left(\frac{\mathrm{S}_{\mathrm{nf}}}{25}\right)\right)$

Where, $P_{m}$ (primary mineralogy, i.e. minerals associated with the original lithology) and $\mathrm{S}_{\mathrm{m}}$ (secondary mineralogy, i.e. minerals associated with alteration processes) are representative values based on the hardness of each mineral present and the relative proportion of each mineral contained in each sample (obtained from thin section or visual examination of samples or drill cuttings). Alteration index (AI) is the percentage of the sample that has changed from the original due to hydrothermal alteration (primary mineral replacement, infilling of fractures and voids), and acts to scale $\mathrm{P}_{\mathrm{m}}$ and $\mathrm{S}_{\mathrm{m}}$ according to

Table 2

The semi-quantitative categories for the secondary minerals and the percentages representing the categories.

\begin{tabular}{|c|c|c|c|c|c|c|c|c|c|c|c|}
\hline \multirow[t]{2}{*}{ Ranking } & 1 & 2 & 3 & 4 & 5 & 6 & 7 & 8 & \multirow{2}{*}{$\frac{9}{-}$} & \multirow[t]{2}{*}{10} & \multirow[t]{2}{*}{11} \\
\hline & \multicolumn{8}{|c|}{ Representative percentages of secondary minerals } & & & \\
\hline Abundant (A) & 50 & & & & & & & & & & \\
\hline Common $(\mathrm{C})$ & 45 & 40 & 35 & 30 & 25 & & & & & & \\
\hline Minor (M) & & 20 & 17.5 & 15 & 12.5 & 10 & 7.5 & 5 & & & \\
\hline Rare (R) & & & 5 & 4.5 & 4 & 3.5 & 3 & 2.5 & 2 & 1.5 & 1 \\
\hline
\end{tabular}

Table 3

Hardness index values assigned to Moh's hardness.

\begin{tabular}{cl}
\hline Moh's hardness scale & Hardness index \\
\hline$>7$ & 2.1 \\
$7-6$ & 1.7 \\
$6-4.5$ & 1.3 \\
$4.5-3$ & 0.9 \\
$3-2$ & 0.5 \\
$<2$ & 0.1 \\
\hline
\end{tabular}

relative percentage alteration. This portion of the equation, the mean mineralogy parameter, accounts for the overall impact of all mineral types on the strength.

$\Phi$ is the connected porosity, as a volume \%, which is related to both original porosity and changes in porosity due to mass exchange during hydrothermal alteration processes. It is multiplied to the mineralogy portion of the equation in order to have a power law-based impact on the strength estimate, where the higher the porosity, the lower the strength.

To represent the presence of fractures, the fracture index, $\mathrm{S}_{\mathrm{nf}}$ a number between 0 (no fractures) and 6 (multiple large open fractures), is assigned to each sample. This parameter is multiplied to the mineralogy and porosity portions of the equation to reduce the strength index value based on the severity of fracturing.

\subsection{Alteration strength index (ASI) development}

\subsubsection{Mineralogy $\left(P_{m}\right.$ and $\left.S_{m}\right)$ and alteration index $(A I)$}

Primary and secondary mineralogy both influence the strength of rocks, where rocks with predominately weak minerals lead to a lower strength compared to rocks containing predominantly strong minerals (Vutukuri et al., 1974; Rigopoulos et al., 2010; Li et al., 2012; Villeneuve et al., 2012). We developed a method for deriving a representative percentage of the primary and secondary minerals to address this. Identifying the exact percentages of minerals in hydrothermally altered samples can be difficult (Stringham, 1952), and identifying alteration mineralogy, including clay, requires complex separation and thorough XRD analysis (Hillier, 2000), which are not suitable for rapid, field application. Consequently, the mineral analysis in our study was completed using modal percentage estimates from thin sections.

To determine the modal percentages of the primary and secondary minerals the primary and secondary minerals need to be identified. The identified minerals are then assigned representative modal percentages. The primary mineralogy is accounted for by assigning a semi-quantitative category: abundant $(A)$, common $(C)$, minor $(\mathrm{M})$ and rare $(\mathrm{R})$, related to abundance in thin section. A representative

\section{Table 4}

An example of how to determine the primary and secondary values of the mineralogy parameter that is multiplied by the alteration index (AI). The assigned percentage is multiplied by the hardness index and added together to produce the resulting $\mathrm{P}_{\mathrm{m}}$ and $\mathrm{S}_{\mathrm{m}}$ values.

\begin{tabular}{|c|c|c|c|}
\hline Category & Mineral & Assigned percentage & Hardness index \\
\hline \multicolumn{4}{|c|}{ Primary mineral $\left(P_{m}\right)$} \\
\hline A & Plagioclase & 25 & 1.7 \\
\hline M & Quartz & 10 & 2.1 \\
\hline \multicolumn{4}{|l|}{$P_{m}=35.7$} \\
\hline \multicolumn{4}{|c|}{ Secondary mineral $\left(S_{m}\right)$} \\
\hline A & Quartz & 50 & 2.1 \\
\hline C & Calcite & 40 & 0.9 \\
\hline $\mathrm{C}$ & Epidote & 35 & 1.7 \\
\hline $\mathrm{R}$ & Chlorite & 4.5 & 0.5 \\
\hline $\mathrm{S}_{\mathrm{m}}=202$ & & & \\
\hline
\end{tabular}




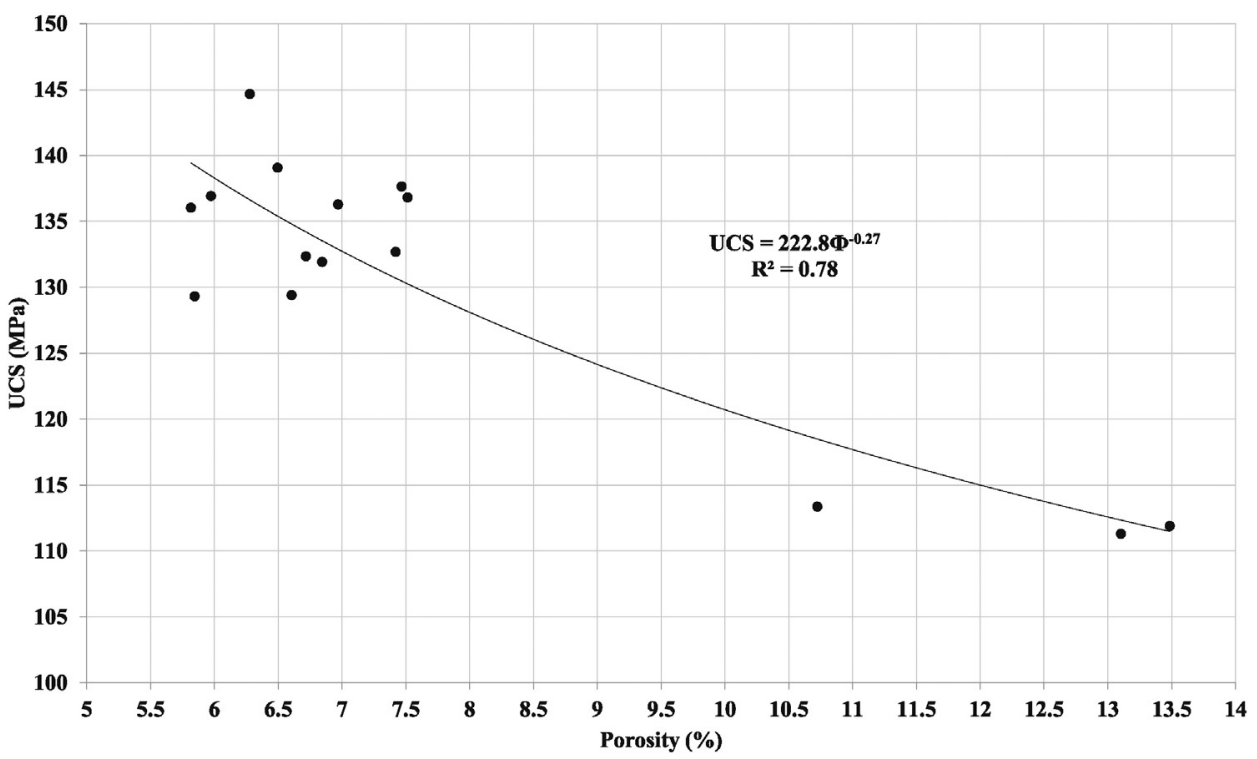

Fig. 2. Relationship between uniaxial compressive strength (UCS) and porosity for the Rotokawa andesite samples.

percentage of $50,25,10,5$, respectively, is assigned to each semiquantitative category (Table 1 ).

This is repeated for the secondary minerals; however, due to the abundance and variety of the secondary minerals typically found in hydrothermally altered rocks, the semi-quantitative categories are additionally ranked between 1 and the total number of secondary minerals within each category (Table 2). This allows for samples with multiple minerals that are abundant, common, minor or rare. Table 2 illustrates the representative percentages of the secondary minerals based on this ranking. If a sample has chlorite as a common (C) mineral, but it is the 3rd most common mineral, it would be assigned a representative value of 35 .

Vutukuri et al. (1974) reported that there is a positive relationship between the hardness of minerals present in the rock and rock strength. We, therefore, used hardness as a proxy for mineral strength to estimate the aggregate strength of a sample. To determine whether a mineral is to be classified as soft or hard in the ASI equation, we took minerals with Moh's hardness less than 5 to be soft and minerals with Moh's hardness greater than 5 to be hard, as described in Broz et al. (2006) and Whitney et al. (2007). The minerals were assigned hardness index values from $0.1-2.1$. Soft minerals were assigned hardness index value less than $1(0.1-0.9)$ because their presence tends to 'weaken' the rock, while hard minerals were assigned hardness index value greater than $1(1.3-2.1)$ because their presence tends to 'strengthen' the rock (Table 3).

The hardness index parameter for a mineral in a sample is multiplied by its representative percentage value to obtain $\mathrm{P}_{\mathrm{m}}$ and $\mathrm{S}_{\mathrm{m}}$ for primary and secondary minerals, respectively (See Table 4 for a worked example). The result is that an abundant mineral has a greater influence on the whole rock strength estimate than a mineral with low abundance. The approximate proportion of primary versus secondary mineralogy is estimated, and this produces the alteration index (AI), e.g. a value of 50 represents a sample with half primary and half secondary minerals. The summed mineralogical influences for primary and secondary minerals are then weighted using the AI value to conclude the mean mineralogy parameter portion of the ASI equation.

Future studies could make use of Scanning Electron Microscope (SEM) in the form of Quemscan or robust analysis of Energy Dispersive Spectrometry (EDS) maps and spectra alongside optical petrology to assist in quantifying the mineralogy percentages in a research environment; however as mentioned previously this is unlikely to be feasible to carry out in-field for real-time analysis.

\subsection{Porosity $(\Phi)$}

Igneous rocks can be intrusive - made primarily of interlocking crystals, extrusive - composed of phenocrysts and groundmass (which may be microcrystalline or contain glass), or pyroclastic - composed of grains of crystals, glass, and rock that are cemented or welded together. Porosity in rocks is fundamentally controlled by the efficiency and extent of outgassing of the magma. The porosity is present as bubbles (in magma) and can be preserved as vesicles (in volcanic rock) (Dobson et al., 2003; Shea et al., 2010; Heap et al., 2014b). As alteration occurs the porosity within a sample can increase or decrease through mass transfer with dissolution and precipitation of minerals as the fluids permeate through the rocks, thereby creating or infilling voids (Ferry, 1979; Giggenbach, 1984; Henneberger and Browne, 1988; Reyes, 1990; Simmons and Browne, 2000; Esmaeily et al., 2012). The pore structure is dependent on numerous factors such that the porosity within a rock can vary greatly (Hudyma et al., 2004; Heap et al., 2014b). Porosity is an important factor in rock strength, because voids reduce the integrity of the material and, as indicated by the ISRM (Ulusay and Hudson, 2007a), even a small volume of pores can have a noticeable mechanical effect (Sammis and Ashby, 1986; Fakhimi and Gharahbagh, 2011; Heap et al., 2014a, 2014b). Pores reduce stiffness and strength due to stress concentration on the boundary of the pores. Additionally, the pores

Table 5

Values assigned to the samples based on the fractures seen in thin section and on the bulk rocks.

\begin{tabular}{|c|c|c|}
\hline $\begin{array}{l}\text { Fracture } \\
\text { value }\left(S_{\text {nf }}\right)\end{array}$ & Fracture type & Fracture size \\
\hline 0 & No fractures in sample & - \\
\hline 1 & $\begin{array}{l}\text { Microfractures seen in } \\
\text { thin section }\end{array}$ & Narrow fractures in thin section \\
\hline 2 & Small fracture - closed & $\begin{array}{l}1 \text { fracture }<1 \mathrm{~mm} \text { in width, }<10 \mathrm{~mm} \text { in } \\
\text { length and fracture remains closed }\end{array}$ \\
\hline 3 & Small fracture - open & $\begin{array}{l}1 \text { fracture }<1 \mathrm{~mm} \text { in width, }<10 \mathrm{~mm} \text { in } \\
\text { length and fracture remains opened }\end{array}$ \\
\hline 4 & Large fracture - closed & $\begin{array}{l}1 \text { fracture }>1 \mathrm{~mm} \text { in width, }>10 \mathrm{~mm} \text { in } \\
\text { length and fracture remains closed }\end{array}$ \\
\hline 5 & Large fracture - open & $\begin{array}{l}1 \text { fracture }>1 \mathrm{~mm} \text { in width, }>10 \mathrm{~mm} \text { in } \\
\text { length and fracture remains open }\end{array}$ \\
\hline 6 & $\begin{array}{l}\text { Multiple large fractures - } \\
\text { closed/open }\end{array}$ & $\begin{array}{l}2 \text { or more fractures }>1 \mathrm{~mm} \text { in width, } \\
>10 \mathrm{~mm} \text { in length }\end{array}$ \\
\hline
\end{tabular}




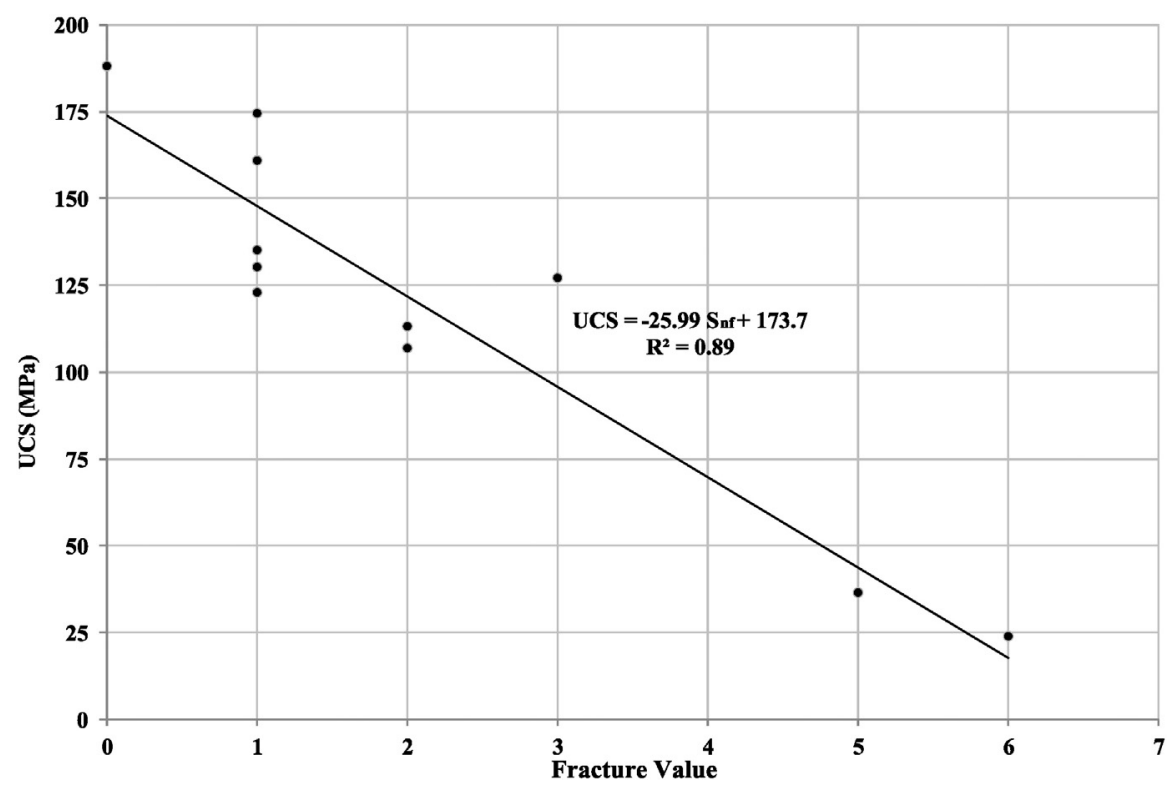

Fig. 3. Relationship between uniaxial compressive strength (UCS) and fracture values for the Ngatamariki andesite samples.

may be filled with fluids, which may help in crack propagation under compression due to the incompressibility of the fluids, leading to an increase in stress concentrations at pore boundaries as the fluid is trying to escape (Price, 1960; Lama and Vutukuri, 1978; Luping, 1986; Baud et al., 2000, 2009; Brantut et al., 2013).

The measurement of porosity likely includes the presence of preexisting, open fractures, because the saturation fluid is able to infiltrate these fractures during saturation. In our equation, the fracture index $\left(\mathrm{S}_{\mathrm{nf}}\right)$ accounts explicitly for the high potential for failure along preexisting, but closed or incipient, fractures, that have less proportional influence on the measurement of porosity than pores, due to their smaller void volume (Mueller et al., 2005). In Wyering et al., 2014, samples with open fractures tended to break during sample preparation and thus tended to be excluded from the data set.

To isolate the impact of porosity on UCS we used the Rotokawa andesite samples (Siratovich et al., 2014; Wyering et al., 2014), which have similar mineralogy and fracture characteristics (fracture index values of $0-1$ ) with each other. We found that gaps in the data made the decision between power, log or linear trends between the porosity and UCS in our data difficult. We selected an inverse power relationship because many authors have reported an inverse power correlation for a variety of rock types (Lama and Vutukuri, 1978; Palchik, 1999; Begonha and Sequeira Braga, 2002; Li and Aubertin, 2003; Sousa et al., 2005; Chang et al., 2006; Heap et al., 2014b). We have used the resulting inverse power correlation (Fig. 2 ), with the power constant -0.13 , in the ASI equation based on this analysis.

\subsection{Fracture index $\left(S_{n f}\right)$}

Some of the core used in the Wyering et al., 2014 study contained pre-existing fractures and veins, making preparation difficult. There are three types of fractures possible in a rock: intergranular - occur between grain, intragranular - occur within a grain, and transgranular affect more than one grain (Sousa et al., 2005). The majority of the preexisting fractures in the samples used for this study are transgranular. Micro- and macrofractures, whether pre-existing or induced during testing, coalesce during uniaxial compression ultimately leading to failure of the sample (Bieniawski, 1967; Bieniawski et al., 1969). Samples that contain pre-existing fractures require less energy to propagate the fractures, resulting in lower peak strength values in these samples (Walsh, 1961; Martin, 1997; Siratovich et al., 2014).
Studies investigating the impact of controlled microstructural damage in rocks found that peak strength is sensitive to the amount of induced damage, resulting in lower peak strengths (Martin, 1997; Heap et al., 2015). Wyering et al., 2014 show the same results for the andesite breccia from Ngatamariki, where 11 out of 29 samples had pre-existing fractures. The samples that contained pre-existing fractures had a mean UCS of $32.4 \pm 7.3 \mathrm{MPa}$ and an average porosity of $2.2 \%$ ( samples NM7-5, 7-8, 7-12), while the remaining samples had a mean strength of $117.5 \pm 45.9 \mathrm{MPa}$ and average porosity of $1.6 \%$. To account for this we selected index values for $S_{n f}$ between 0 and 6 for seven different categories of visible macrofractures, in order of severity. Consequently, a large fracture through the bulk sample is assigned a higher value than a sample that has evidence of many thin short microfractures in thin section (Table 5).

To isolate the impact of pre-existing fractures on UCS we used a subset of the Ngatamariki andesite breccia samples that had similar primary and secondary mineralogy and porosity (ranging from 1.4-2.3\%). The relationship between UCS and fractures is linear and negative (Fig. 3), and we derived the formulation $\left(1-\mathrm{S}_{\mathrm{nf}} / 25\right)$ used in the ASI equation from this fit. This formulation results in no impact if there are no fractures $\left(S_{n f}=0\right)$, and greater strength reduction as the severity of fractures increases ( $S_{\text {nf }}=1$ to 6 ). The constant $1 / 25$ scales the $0-6$ range for $\mathrm{S}_{\mathrm{nf}}$ based on the results from the andesite breccia.

To allow for the use of the fracture parameter if only drill cutting are available, the veining abundance could be used as a substitute. Fractures in geological systems are important conduits for fluid flow (Wangen and Munz, 2004; Rawal and Ghassemi, 2010). Ion rich hydrothermal fluids travel through fractures, textures and faults depositing secondary minerals creating veins. We assume that veining corresponds to fractures to use veining as a basis for fracture estimating. The veining abundance substitute values are displayed in Table 6. We have used fractures from core to produce the values in this study; however, this can be difficult if the drill cuttings are small.

Table 6

Fracture parameter substitute for the drill cuttings.

\begin{tabular}{ll}
\hline Veining abundance & Snf \\
\hline No veins in samples $(\mathrm{R})$ & 0 \\
Micro veins $(\mathrm{M})$ & 1 \\
Small veins in the cuttings $<1 \mathrm{~mm}(\mathrm{C})$ & 2 \\
Large veins in the cuttings $>1 \mathrm{~mm}(\mathrm{~A})$ & 4 \\
\hline
\end{tabular}




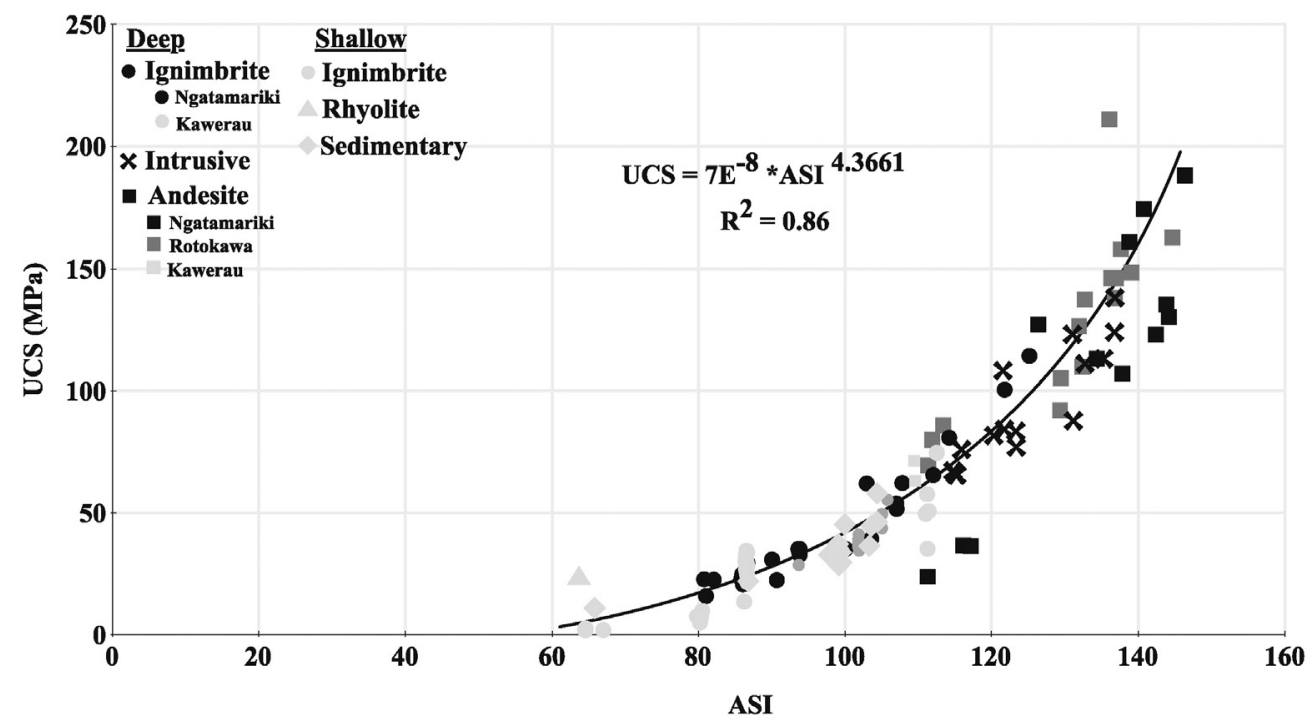

Fig. 4. Relationship between alteration strength index (ASI) and uniaxial compressive strength (UCS) showing a power relationship.

\section{Discussion}

The ASI equation has been developed as a tool to rapidly estimate the range of strengths for a hydrothermally altered rock based on its present geological characteristics using data collection techniques currently used in field mapping and drilling exploration. In principle, original lithology and texture will likely affect rock strength, but the process for interpreting original lithology and texture do not lend themselves to rapid strength estimation. We have devised the ASI to use rock characteristics that are easily observed and quantified in the field, irrespective of its original lithology, and to relate them to laboratory strength values, such as UCS.

Wyering et al., 2014 prepared the samples used to devise this equation for UCS testing according to internationally recognized standards (ISRM/ASTM). The presence of fractures influences the tested rock strength (Fig. 3), which, according to ISRM and ASTM standards would result in "invalid" tests. These fractures will impact drilling performance, thus the need to include fractures to derive strength estimates applicable to drilling. We have devised the Snf parameter to allow the ASI equation to provide ranges of strength for different formations and lithologies based on different rock conditions/properties, including pre-existing fractures. Values used to calculate ASI from the Ngatamariki, Rotokawa and Kawerau Geothermal fields are in Appendix A Table A.1. The correlation of ASI to measured UCS (Fig. 4) shows a clear trend $\left(r^{2}\right.$ of 0.86$)$ - such that the ASI can be used to predict the UCS rock strength. To convert the ASI value to UCS Eq. (2) can be used. Our dataset does not include samples with ASI values below 60, however rocks with such low ASI could be encountered, for example if samples have extremely high porosity. According to Fig. 4 and Eq. (2), however, the strength would be so low as to barely be classified as rocks. The UCS results from both laboratory tests and estimated from ASI are in Appendix A, Table A.2.

$\mathrm{UCS}=7 \times 10^{-8} \times \mathrm{ASI}^{4.3661}$

The empirical fit on which Eq. (2) is based contains variability and the UCS calculated from the ASI should always be quoted with a range of error. This will allow for the range to cover natural variations in the

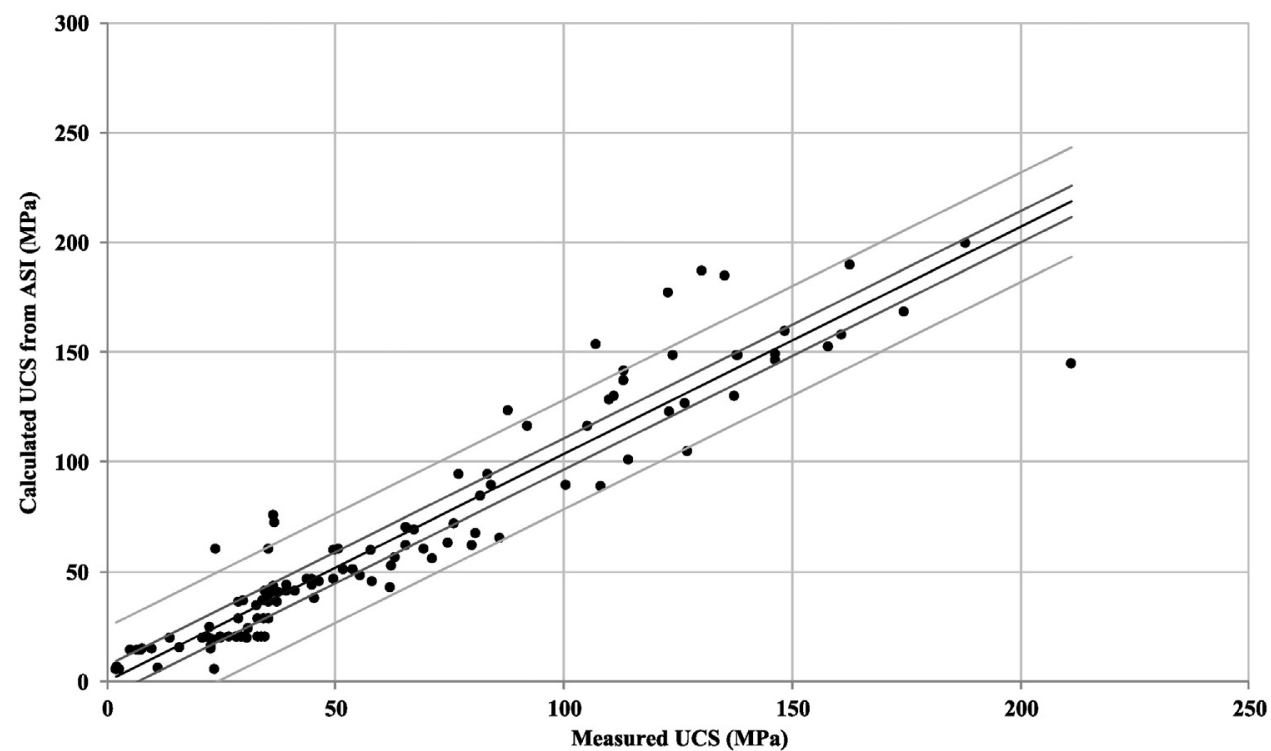

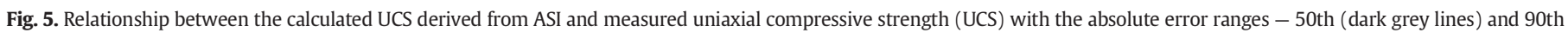
percentile (light grey lines). 


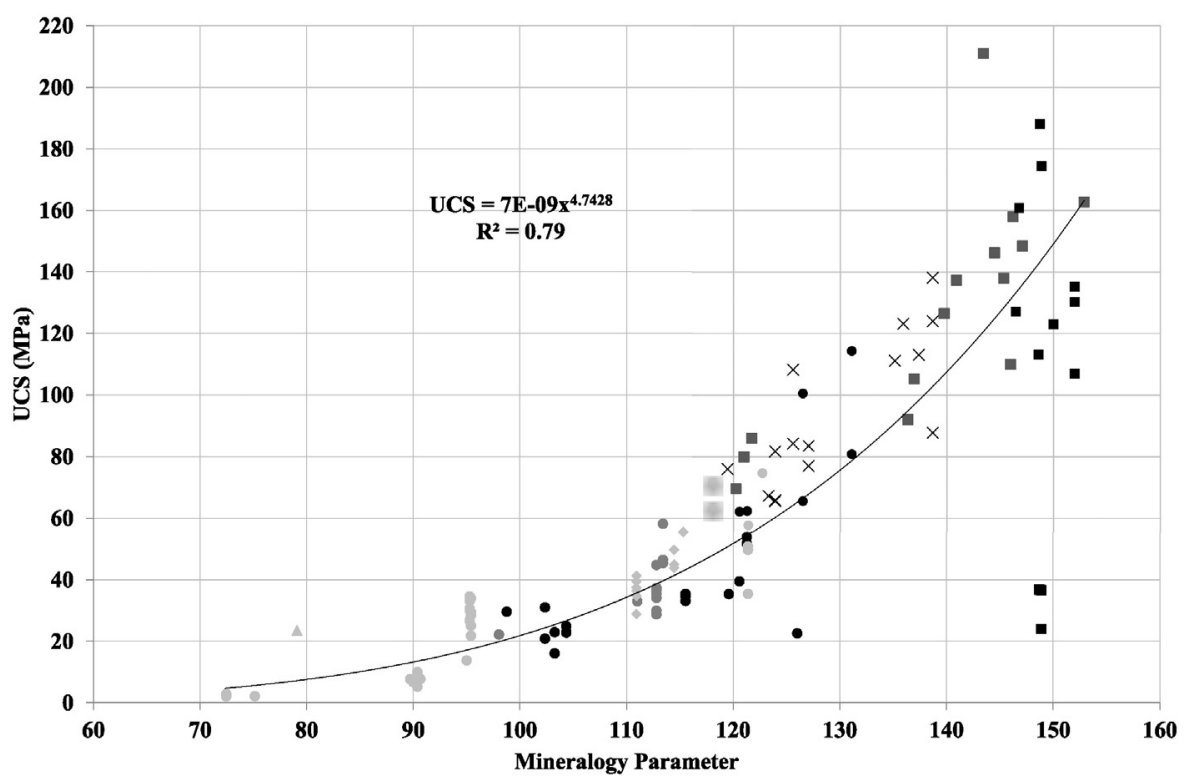

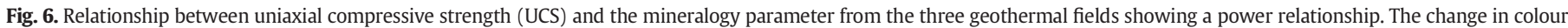

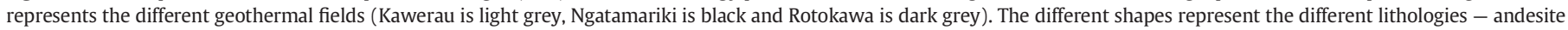
(square), ignimbrite (circles), intrusive (crosses), sedimentary (diamonds) and rhyolite (triangles).

rock and error arising from visual examinations of mineral abundance. The 50th and 90th percentile absolute error ranges for this dataset are $\pm 7 \mathrm{MPa}$ and $\pm 25 \mathrm{MPa}$ respectively, with a mean error of $\pm 11 \mathrm{MPa}$. This error value could be used to represent this variability. Fig. 5 shows a plot of calculated UCS from ASI against measured UCS from testing and also shows the position of these 50th and 90th percentile error ranges.

\subsection{Modified alteration strength index (mASI)}

To explore the potential for a modified ASI, based on fewer input parameters, we plotted each parameter in the ASI equation against UCS to examine its overall influence on the result (Figs. 6-8). Fig. 6 illustrates the strong relationship observed between the mineralogy parameter and the measured UCS.

The mineralogy aspects of the Rotokawa andesite and Kawerau andesite (order of the top three secondary minerals and alteration intensity, with calculated mean mineralogy parameter) and measured UCS are shown in Table 7. The order of abundance of the main minerals namely quartz and chlorite, demonstrates how the abundance and hardness of minerals would cause an increase or decrease in the mean mineralogical parameter. The comparison to UCS shows that the mean mineralogy parameter alone indicates that the Rotokawa andesite is stronger than the Kawerau andesite.

The mean mineralogy parameter with either the fracture parameter or the porosity parameter versus measured UCS (Figs. 7 and 8, respectively) show weaker correlations than the complete ASI correlation (Fig. 3). The deep ignimbrites from Ngatamariki have clusters with similar mineralogy (black circles, Fig. 6), however when the fracture parameter, which spans the full range (0-6) (Fig. 7) or the porosities (3\%-20\%) (Fig. 8) are taken into account, the points no longer cluster and are well spread along the data trendline.

These observations show that the mean mineralogy parameter is the dominant characteristic in the ASI equation; however, the inclusion of

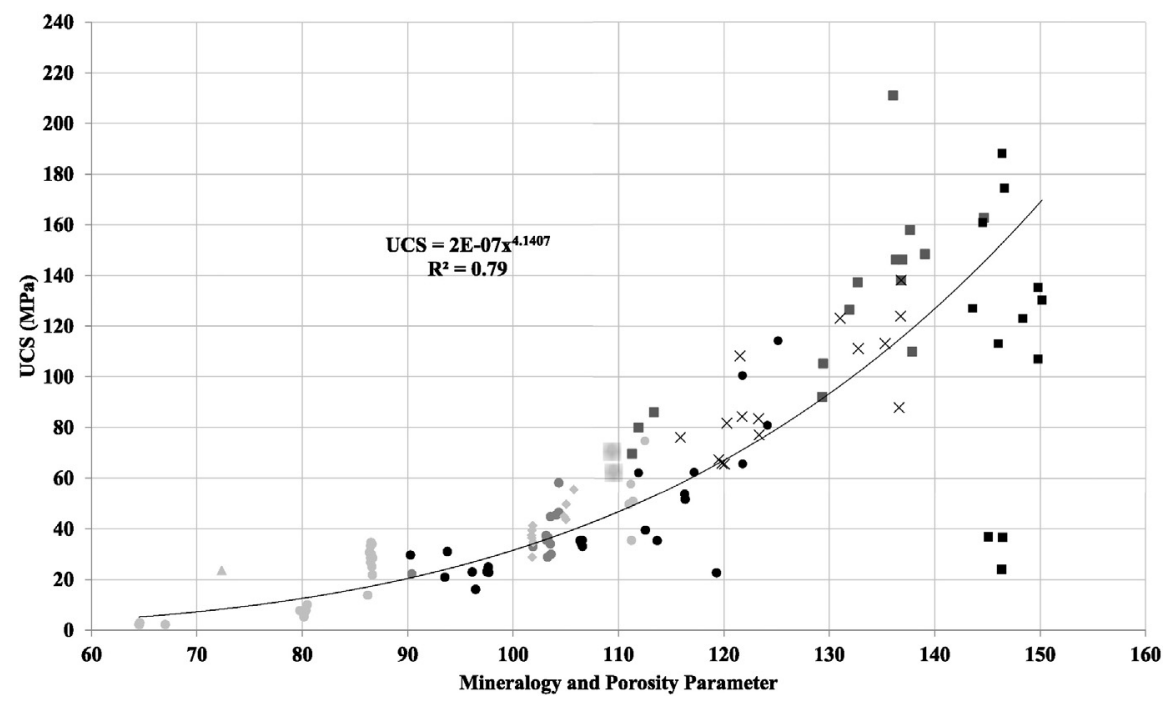

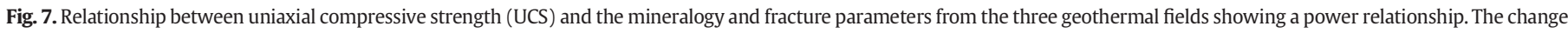

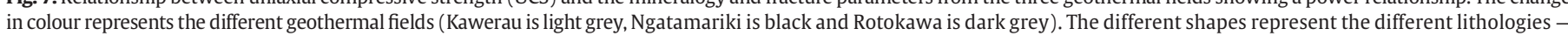
andesite (square), ignimbrite (circles), intrusive (crosses), sedimentary (diamonds) and rhyolite (triangles). 


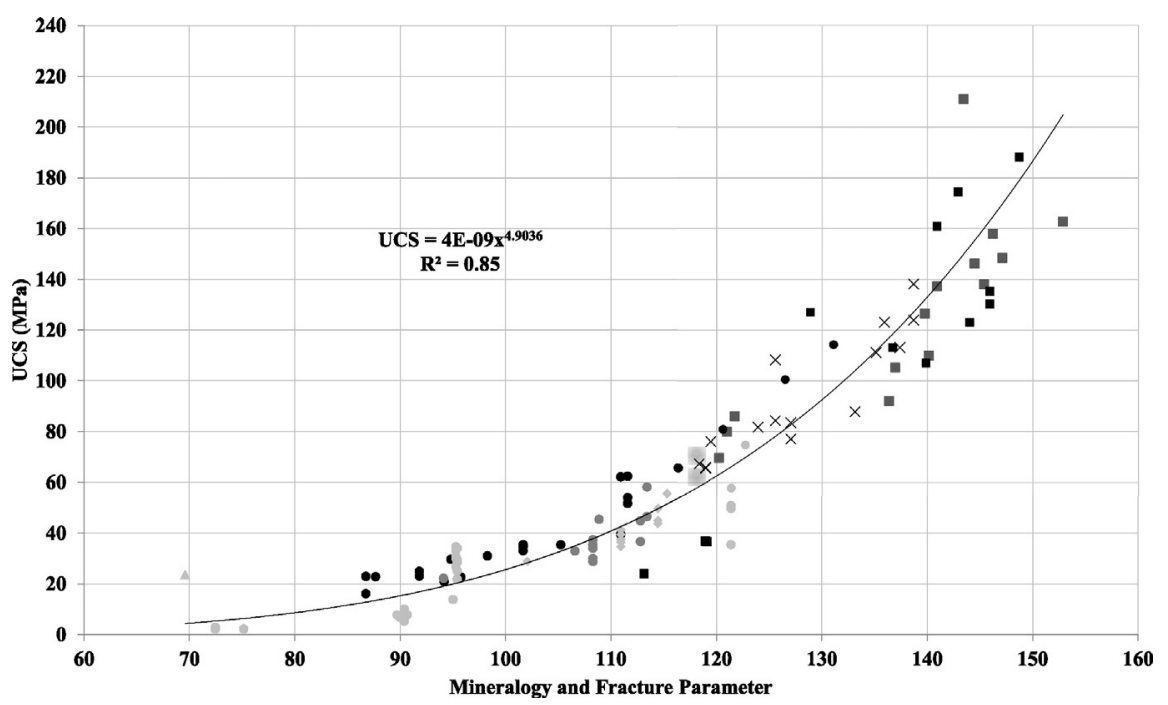

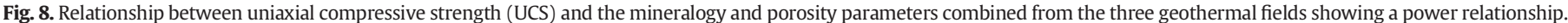

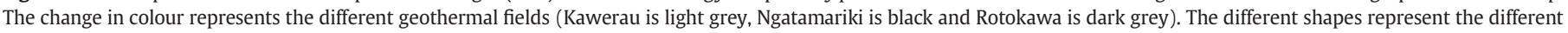
lithologies - andesite (square), ignimbrite (circles), intrusive (crosses), sedimentary (diamonds) and rhyolite (triangles).

the effects of porosity and fractures leads to a stronger relationship with UCS (Fig. 4). The best way to use ASI is in its original form, however if porosity or pre-existing fracture or veining data are unavailable, good predictions of UCS are still possible. For example when using drill cuttings, if porosity and fracture data are not available the mASI equation using the mean mineralogy parameter alone can be used $\left(\mathrm{r}^{2}\right.$ of 0.79 ) (Fig. 6). The 50th and 90th percentile absolute error ranges for this dataset are $\pm 9 \mathrm{MPa}$ and $\pm 44 \mathrm{MPa}$ respectively, with a mean error of $\pm 18 \mathrm{MPa}$. The fracture parameter shows a much greater improvement of the fit of the mASI ( $r^{2}$ of 0.85 ) (Fig. 7) than the porosity data ( $r^{2}$ of 0.79 ) (Fig. 8). The 50th and 90th percentile absolute error ranges for this dataset are $\pm 8 \mathrm{MPa}$ and $\pm 24 \mathrm{MPa}$ respectively, with a mean error of $\pm 11 \mathrm{MPa}$. Although the difference between mASI with only the mean mineralogy parameter and mASI with mean mineralogy parameter and porosity is negligible in terms of $r^{2}$, it is worth noting that the presence of the porosity parameter in ASI leads to a slight improvement in the correlation between measured UCS and ASI $\left(r^{2}\right.$ of 0.86 ) (Fig. 4) over mASI with mean mineralogy parameter and fracture parameter only. When using the mASI it is necessary to be aware of the reduction in accuracy of the prediction of UCS, as reflected in the wider error ranges. The mASI could be used to give a first estimate of the rock strength from drill cuttings. When possible thin section can be make of the cuttings and analysed in further detail on site with the correct equipment. The additional effort will provide additional confidence in the results through better mineralogy and fracture/veining abundance observations.

\subsection{Predictive capabilities}

It is important to understand how hydrothermal alteration has influenced the rock properties of a lithology in order to make strength-based decisions for engineering works in geothermal settings. For example, predicting strength changes can improve drilling efficiency and help guide drill bit selection. The ASI equation can be used in the lab or in the field to provide a range of strengths. The ASI equation has been calibrated with hydrothermally altered rocks from three different geothermal fields with diverse primary lithologies from both shallow and deep alteration zones typical of the TVZ and should be suitable for any hydrothermally altered rocks in this area. The samples tested represent a majority of lithologies found in a variety of geothermal fields that are exposed to differing hydrothermal environments. Because the ASI provides ranges of rock strengths it can be used to provide a first-pass estimate for strength for hydrothermally altered rocks in similar environments, although further testing is necessary to determine if the constants require calibration. Therefore, should this equation be used in active or non-active geothermal environments with different lithologies than those tested in this study, a user could tests the ASI vs. UCS (Fig. 4) relationship for the new lithologies and modify the equation to suit the new environment. If this is not possible, it should prove a good first-pass for estimating rock strength. Any additional information added to the results will only but improve the reliability of the equation.

This research has also allowed us to provide ranges of rock strengths based solely on the alteration zones, mineralogy, and depth of lithologies found in a typical geothermal field that can be used to update conceptual models of geothermal fields (Fig. 9). This does not include rock softening due to increased temperature from the geothermal gradient (Karfakis, 1985; Kusznir and Park, 1987; Weinberg and Podladchikov, 1994) or compactant modes of failure for porous rock at depth (Heap et al., 2015). This conceptual model adds an important element to understanding how rock mechanics plays a part in a geothermal system, and can be a fundamental addition to the geothermal industry to support drilling, wellbore stability studies and mechanical modelling.

\section{Conclusions}

1. We developed the alteration strength index (ASI) equation to predict rock strength based on different geological characteristics, including mineralogy, fractures and porosity for hydrothermally altered rocks. It has been developed so that only the mineralogy, porosity and fracture state are needed to rapidly determine a range of rock strengths

Table 7

The top three minerals, alteration intensity, mean mineralogy parameter and UCS (MPa) of the andesite lithology from Rotokawa and Kawerau.

\begin{tabular}{|c|c|c|c|c|}
\hline Lithology & Top three minerals & Alteration intensity & Mean mineralogy parameter & Mean UCS \\
\hline Rotokawa Andesite & Calcite, quartz and chlorite & $70-95 \%$ & 139.1 & 127.8 \\
\hline Kawerau Andesite & Calcite, chlorite and quartz & $95 \%$ & 118.13 & 67.2 \\
\hline
\end{tabular}




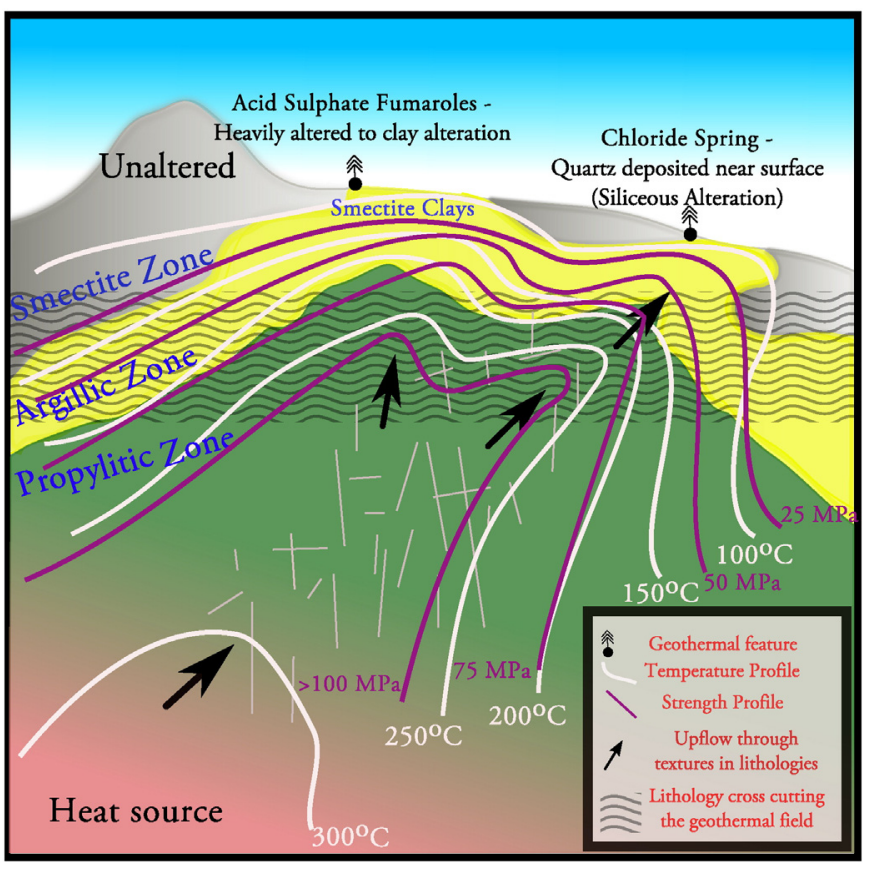

Fig. 9. Conceptual model of a conventional, hot, liquid dominated geothermal field. The model has been split into the alteration zones typical for a geothermal field, with temperature profiles, surface expressions with the addition of strength profiles (adapted from Cumming, 2009).

for any hydrothermally altered rocks, whether in active or non-active geothermal systems.

2. To represent a variety of alteration zones and resulting alteration mineralogy, a range of lithologies were tested from core sampled from the Ngatamariki, Rotokawa and Kawerau geothermal fields in the Taupo Volcanic Zone. These rocks include shallow and deep formations of extrusive and intrusive rocks that contained large quantities of primary and secondary minerals including but not limited to clays, quartz, calcite, chlorite, albite, pyrite and epidote.

3. Our results show a strong relationship between ASI and measured UCS ( $R^{2}$ of 0.86 ), and were used to derive an equation to convert ASI to UCS. The 50th and 90th percentile absolute error ranges of this relationship are $\pm 7 \mathrm{MPa}$ and $\pm 25 \mathrm{MPa}$ respectively, with a mean error of $\pm 11 \mathrm{MPa}$. These can be used to define ranges of estimated rock strength.

4. The mineralogy is the dominant characteristic in this equation, and forms one possible modified ASI ( $\mathrm{mASI}$ ) formulation, however a larger error range is specified for $\mathrm{mASI}$. The inclusion of pre-existing fractures in addition to mineralogy makes the relationship of mASI to UCS stronger. The inclusion of porosity data only shows improvement in correlation to UCS for the ASI is in its original form. This makes our approach functional in a field setting to provide realtime strength estimates during engineering works, such as drilling or excavation, where porosity and pre-existing fractures can be difficult to assess.

5. The conceptual model of geothermal systems with alteration zones, temperature profiles and fluid path migration with associated rock strength profiles based on the ASI shown in Fig. 9 adds an important element to understanding how rock mechanics plays a part in a geothermal system. This can form the basis for constructing site-specific (including actual stratigraphy, unit and temperature depths, and structural data) conceptual models, which is a valuable addition to the information needed by the geothermal industry to support drilling optimization, wellbore stability studies and mechanical, structural and hydrogeological modelling.

\section{Conflict of interests}

The authors declare that they have no competing interest.

\section{Acknowledgements}

The authors wish to thank Mighty River Power, Rotokawa Joint Venture Limited; a joint venture between the Tauhara North No.2 trust and Mighty River Power Limited, and Ngati Tuwharetoa Geothermal Assets Limited, for the use of core supplied for this study. The staff of the Department of Geological Sciences at the University of Canterbury was invaluable in assisting in all aspects of this research. The Brian Mason Trust also provided for funding for the collection and transportation of the core to the University of Canterbury. The Callaghan Innovation (contract number: MRPR1201/32965) and Source to Surface programme, a multiyear research initiative between the University of Canterbury and Mighty River Power who provided funding for the completion of fieldwork and core collection.

\section{Appendix A}

Table A.1

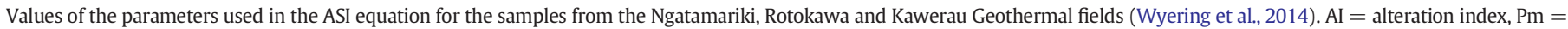
primary mineralogy, $\mathrm{Sm}=$ secondary mineralogy, $\mathrm{Snf}=$ fracture factor, $\Phi=$ porosity.

\begin{tabular}{|c|c|c|c|c|c|c|}
\hline & Sample ID & AI & $\mathrm{Pm}$ & $\mathrm{Sm}$ & Snf & $\Phi$ \\
\hline Shallow formations & G1 Box 13 1-1 & 0.85 & 186.0 & 79.4 & 0 & 25.64 \\
\hline \multirow[t]{16}{*}{ Rhyolitic ignimbrite } & G1 Box 13 1-2 & 0.85 & 186.0 & 79.4 & 0 & 25.14 \\
\hline & G1 Box 13 1-3 & 0.85 & 186.0 & 79.4 & 0 & 24.75 \\
\hline & G1 Box 13 2-1 & 0.85 & 183.3 & 79.4 & 0 & 25.51 \\
\hline & G1 Box 13 2-2 & 0.85 & 186.0 & 79.4 & 0 & 24.79 \\
\hline & G1 Box 13 2-3 & 0.85 & 186.0 & 79.4 & 0 & 25.40 \\
\hline & G1 Box 13 2-4 & 0.85 & 186.0 & 79.4 & 0 & 26.51 \\
\hline & G1 Box 11 1-1 & 0.85 & 183.3 & 110.5 & 0 & 19.80 \\
\hline & G1 Box 11 1-2 & 0.85 & 183.3 & 110.5 & 0 & 17.58 \\
\hline & G1 Box 11 1-3 & 0.85 & 183.3 & 110.5 & 0 & 18.37 \\
\hline & G1 Box 11 1-4 & 0.85 & 183.3 & 110.5 & 0 & 18.79 \\
\hline & G1 Box 112 & 0.85 & 192.2 & 110.5 & 0 & 18.15 \\
\hline & G1 Box 171 & 0.8 & 196.7 & 41.4 & 0 & 46.32 \\
\hline & G1 Box 17 2-1 & 0.8 & 196.7 & 44.8 & 0 & 46.06 \\
\hline & G1 Box 17 2-2 & 0.8 & 196.7 & 41.4 & 0 & 47.48 \\
\hline & G1 Box 173 & 0.8 & 196.7 & 41.4 & 0 & 46.73 \\
\hline & G1 Box 174 & 0.8 & 196.7 & 41.4 & 0 & 48.03 \\
\hline
\end{tabular}


Table A.1 (continued)

\begin{tabular}{|c|c|c|c|c|c|c|}
\hline & Sample ID & AI & $\mathrm{Pm}$ & $\mathrm{Sm}$ & Snf & $\Phi$ \\
\hline Shallow formations & G2 Box 151 & 0.85 & 190.0 & 78.6 & 0 & 25.33 \\
\hline \multirow[t]{9}{*}{ Rhyolitic ignimbrite } & G2 Box 15 2-1 & 0.85 & 190.0 & 78.6 & 0 & 25.28 \\
\hline & G2 Box 15 2-2 & 0.85 & 190.0 & 78.6 & 0 & 24.97 \\
\hline & G2 Box 153 & 0.85 & 190.0 & 78.6 & 0 & 26.29 \\
\hline & G2 Box 154 & 0.85 & 190.0 & 78.6 & 0 & 24.88 \\
\hline & G2 1-1 & 0.95 & 210.0 & 84.1 & 0 & 54.66 \\
\hline & G2 1-2 & 0.95 & 210.0 & 84.4 & 0 & 56.56 \\
\hline & G2 1-3 & 0.95 & 196.7 & 84.4 & 0 & 47.00 \\
\hline & G2 2-1 & 0.95 & 196.7 & 84.1 & 0 & 50.15 \\
\hline & G2 2-2 & 0.95 & 210.0 & 84.1 & 0 & 47.91 \\
\hline Rhyolitic lava & KAM 11 & 0.95 & 190.0 & 73.3 & 3 & 19.54 \\
\hline \multirow[t]{13}{*}{ Siltstone/Sandstone } & КА30 1-1 & 0.8 & 206.4 & 90.2 & 1 & 17.40 \\
\hline & KA30 1-2 & 0.8 & 203.3 & 90.2 & 1 & 16.99 \\
\hline & KA30 2-1 & 0.8 & 206.4 & 90.2 & 0 & 16.10 \\
\hline & КА30 2-2 & 0.8 & 206.4 & 90.2 & 0 & 16.10 \\
\hline & KA30 3-1 & 0.8 & 203.3 & 90.2 & 1 & 17.43 \\
\hline & KA30 3-2 & 0.8 & 203.3 & 90.2 & 0 & 17.27 \\
\hline & КА30 4-1 & 0.8 & 203.3 & 90.2 & 0 & 18.82 \\
\hline & КА30 4-2 & 0.8 & 203.3 & 90.2 & 1 & 18.87 \\
\hline & KA30 4-3 & 0.8 & 203.3 & 90.2 & 1 & 19.44 \\
\hline & КА30 4-4 & 0.8 & 203.3 & 90.2 & 1 & 19.86 \\
\hline & KAW 171 & 0.9 & 190.0 & 87.8 & 1 & 14.95 \\
\hline & KAW17 3-2 & 0.8 & 190.0 & 91.3 & 1 & 17.47 \\
\hline & KAW 17 C2 4 & 1 & 0.0 & 72.3 & 0 & 23.03 \\
\hline Deep formations & NM1 1-2 & 0.9 & 175.0 & 126.2 & 2 & 6.17 \\
\hline \multirow[t]{32}{*}{ Rhyolitic ignimbrite } & NM1 1-1 & 0.9 & 175.0 & 126.2 & 0 & 4.70 \\
\hline & NM2 2-3 & 0.95 & 170.0 & 98.8 & 2 & 20.28 \\
\hline & NM2 2-1 & 0.95 & 170.0 & 98.8 & 1 & 18.60 \\
\hline & NM2 2-2 & 0.95 & 170.0 & 95.0 & 1 & 20.07 \\
\hline & NM $33-2$ & 0.95 & 170.0 & 100.9 & 4 & 9.00 \\
\hline & NM3 3-1 & 0.95 & 170.0 & 100.9 & 3 & 9.52 \\
\hline & NM3 3-3 & 0.95 & 170.0 & 99.8 & 4 & 10.90 \\
\hline & NM3 3-7 & 0.95 & 170.0 & 100.9 & 3 & 9.10 \\
\hline & NM3 3-4 & 0.95 & 170.0 & 99.8 & 4 & 9.79 \\
\hline & NM 4 & 0.98 & 210.0 & 117.8 & 3 & 5.44 \\
\hline & NM 4 & 0.98 & 210.0 & 124.3 & 6 & 6.17 \\
\hline & NM 5 5-2 & 0.85 & 178.0 & 110.4 & 2 & 12.10 \\
\hline & NM 5 5-1 & 0.85 & 178.0 & 110.4 & 2 & 9.90 \\
\hline & NM8A C1-1 & 0.95 & 180.0 & 118.2 & 2 & 4.03 \\
\hline & NM8A C1-2 & 0.95 & 180.0 & 118.2 & 2 & 3.17 \\
\hline & NM8A C1-3 & 0.95 & 180.0 & 123.7 & 2 & 3.57 \\
\hline & NM8A C1-5 & 0.95 & 180.0 & 123.7 & 0 & 3.58 \\
\hline & NM8A C1-6 & 0.95 & 180.0 & 118.2 & 2 & 4.09 \\
\hline & NM11 1-2 & 0.95 & 180.0 & 112.1 & 3 & 15.29 \\
\hline & NM11 1-3 & 0.95 & 180.0 & 112.1 & 3 & 15.74 \\
\hline & NM11 1-4 & 0.95 & 180.0 & 112.1 & 3 & 14.78 \\
\hline & NM11 1-5 & 0.95 & 180.0 & 112.1 & 3 & 14.65 \\
\hline & KA37 1-1 & 0.9 & 190.0 & 102.2 & 0 & 17.21 \\
\hline & KA37 1-2 & 0.9 & 190.0 & 102.2 & 0 & 17.60 \\
\hline & KA37 1-3 & 0.9 & 190.0 & 106.1 & 0 & 17.53 \\
\hline & KA37 1-4 & 0.9 & 190.0 & 106.1 & 0 & 17.68 \\
\hline & KA37 1-5 & 0.9 & 190.0 & 102.2 & 2 & 17.49 \\
\hline & KA37 1-6 & 0.9 & 190.0 & 102.2 & 0 & 17.72 \\
\hline & KA37 1-7 & 0.9 & 190.0 & 102.2 & 0 & 17.79 \\
\hline & KA37 1-8 & 0.9 & 190.0 & 102.2 & 0 & 16.99 \\
\hline & KA37 2-1 & 0.9 & 190.0 & 106.1 & 0 & 18.73 \\
\hline & KA37 2-2 & 0.9 & 198.6 & 106.1 & 0 & 17.86 \\
\hline Andesite & NM 7-1 & 0.9 & 186.0 & 148.2 & 1 & 1.50 \\
\hline \multirow[t]{17}{*}{ Lava/breccia } & NM 7-2 & 0.95 & 180.0 & 147.1 & 0 & 1.69 \\
\hline & NM 7-3 & 0.9 & 186.0 & 148.2 & 1 & 1.63 \\
\hline & NM 7-4 & 0.9 & 186.0 & 148.2 & 2 & 1.63 \\
\hline & NM 7-5 & 0.95 & 180.0 & 147.1 & 5 & 2.27 \\
\hline & NM 7-6 & 0.95 & 183.3 & 148.2 & 1 & 1.45 \\
\hline & NM 7-7 & 0.95 & 178.0 & 147.1 & 2 & 1.80 \\
\hline & NM 7-8 & 0.95 & 183.3 & 147.1 & 6 & 1.76 \\
\hline & NM 7-9 & 0.95 & 183.3 & 147.1 & 1 & 1.67 \\
\hline & NM 7-10 & 0.95 & 180.0 & 144.7 & 3 & 1.95 \\
\hline & NM 7-11 & 0.95 & 186.0 & 144.7 & 1 & 1.66 \\
\hline & NM 7-12 & 0.95 & 183.3 & 147.1 & 5 & 1.74 \\
\hline & КА3 1-2 & 0.95 & 170.0 & 115.4 & 0 & 12.35 \\
\hline & KA3 2 & 0.95 & 170.0 & 115.4 & 0 & 12.92 \\
\hline & RK27L2_21 21.1 C & 0.75 & 170 & 103.6 & 0 & 13.10 \\
\hline & RK27L2_2121 .8 B & 0.75 & 170 & 104.6 & 0 & 13.49 \\
\hline & RK27L2_2121.5 B & 0.75 & 170 & 105.6 & 0 & 10.72 \\
\hline & RK27L2_212 3.2 A & 0.7 & 170 & 122.8 & 0 & 6.61 \\
\hline
\end{tabular}


Table A.1 (continued)

\begin{tabular}{|c|c|c|c|c|c|c|}
\hline & Sample ID & AI & $\mathrm{Pm}$ & Sm & Snf & $\Phi$ \\
\hline \multirow{26}{*}{ Tonalite intrusive } & RK27L2_21 20.4 B & 0.7 & 170 & 132.0 & 0 & 5.82 \\
\hline & RK28_23 10.6 A & 0.8 & 170 & 127.9 & 0 & 5.85 \\
\hline & RK28_23 10.8 C & 0.8 & 170 & 140.0 & 1 & 6.72 \\
\hline & RK28_23 10.9 C & 0.8 & 170 & 133.6 & 0 & 7.42 \\
\hline & RK28_23 13.2 A & 0.85 & 170 & 140.0 & 0 & 6.97 \\
\hline & RK28_23 10.6 C & 0.85 & 170 & 140.0 & 0 & 5.97 \\
\hline & RK30_23 21.0 A & 0.8 & 170 & 132.2 & 0 & 6.84 \\
\hline & RK30_23 22.3 B & 0.85 & 170 & 141.0 & 0 & 7.51 \\
\hline & RK30_23 22.4 A & 0.85 & 170 & 143.1 & 0 & 6.50 \\
\hline & RK30_23 21.1 B & 0.85 & 170 & 142.0 & 0 & 7.47 \\
\hline & RK30_23 21.7 B & 0.9 & 170 & 151.0 & 0 & 6.28 \\
\hline & NM8-NM8A C2 1 & 0.8 & 190.0 & 122.4 & 0 & 3.40 \\
\hline & NM9 1-1 & 0.75 & 190.0 & 101.0 & 1 & 2.82 \\
\hline & NM9 1-2 & 0.75 & 190.0 & 101.9 & 0 & 2.70 \\
\hline & NM9 1-3 & 0.75 & 190.0 & 101.9 & 1 & 3.06 \\
\hline & NM9 1-4 & 0.75 & 196.7 & 101.9 & 0 & 2.83 \\
\hline & NM9 1-5 & 0.75 & 196.7 & 101.9 & 0 & 2.99 \\
\hline & NM9 1-6 & 0.75 & 190.0 & 106.0 & 0 & 2.71 \\
\hline & NM9 1-7 & 0.75 & 190.0 & 106.0 & 0 & 2.67 \\
\hline & NM9 1-8 & 0.75 & 190.0 & 101.9 & 1 & 2.87 \\
\hline & NM9 1-9 & 0.75 & 190.0 & 95.9 & 0 & 2.76 \\
\hline & NM9 2-2 & 0.75 & 183.3 & 119.1 & 0 & 1.81 \\
\hline & NM9 2-3 & 0.75 & 183.3 & 122.1 & 0 & 1.67 \\
\hline & NM9 2-4 & 0.75 & 183.3 & 123.8 & 1 & 1.65 \\
\hline & NM9 2-5 & 0.75 & 183.3 & 123.8 & 0 & 1.59 \\
\hline & NM9 2-6 & 0.75 & 183.3 & 123.8 & 0 & 1.57 \\
\hline
\end{tabular}

Table A.2

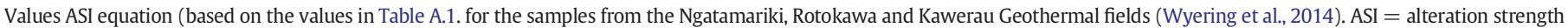
index, UCS (Laboratory) = UCS results from the laboratory testing. UCS (estimated) = The UCS estimates based on Eq. (2).

\begin{tabular}{|c|c|c|c|c|}
\hline & Sample ID & ASI & UCS (laboratory) & UCS (estimated) \\
\hline Shallow formations & G1 Box 13 1-1 & 86.57 & 29.41 & 20.13 \\
\hline \multirow[t]{26}{*}{ Rhyolitic ignimbrite } & G1 Box 13 1-2 & 86.62 & 33.91 & 20.18 \\
\hline & G1 Box 13 1-3 & 86.66 & 28.43 & 20.22 \\
\hline & G1 Box 13 2-1 & 86.22 & 13.73 & 19.78 \\
\hline & G1 Box 13 2-2 & 86.66 & 21.74 & 20.22 \\
\hline & G1 Box 13 2-3 & 86.59 & 25.01 & 20.15 \\
\hline & G1 Box 13 2-4 & 86.48 & 28.48 & 20.04 \\
\hline & G1 Box 11 1-1 & 111.00 & 49.67 & 59.58 \\
\hline & G1 Box 11 1-2 & 111.39 & 50.77 & 60.51 \\
\hline & G1 Box 11 1-3 & 111.24 & 35.39 & 60.17 \\
\hline & G1 Box 11 1-4 & 111.17 & 57.74 & 59.99 \\
\hline & G1 Box 112 & 112.51 & 74.69 & 63.20 \\
\hline & G1 Box 171 & 64.58 & 2.80 & 5.60 \\
\hline & G1 Box 17 2-1 & 66.99 & 2.12 & 6.57 \\
\hline & G1 Box 17 2-2 & 64.53 & 2.05 & 5.58 \\
\hline & G1 Box 173 & 64.56 & 2.19 & 5.59 \\
\hline & G1 Box 174 & 64.51 & 2.21 & 5.57 \\
\hline & G2 Box 151 & 86.48 & 26.75 & 20.04 \\
\hline & G2 Box 15 2-1 & 86.49 & 33.15 & 20.04 \\
\hline & G2 Box $152-2$ & 86.52 & 30.09 & 20.08 \\
\hline & G2 Box 153 & 86.38 & 30.61 & 19.94 \\
\hline & G2 Box 154 & 86.53 & 34.56 & 20.09 \\
\hline & G2 1-1 & 80.17 & 5.21 & 14.39 \\
\hline & G2 1-2 & 80.34 & 7.69 & 14.53 \\
\hline & G2 1-3 & 80.19 & 6.66 & 14.41 \\
\hline & G2 2-1 & 79.78 & 7.63 & 14.09 \\
\hline & G2 2-2 & 80.48 & 9.97 & 14.64 \\
\hline Rhyolitic lava & KAM 11 & 63.67 & 23.46 & 5.26 \\
\hline \multirow[t]{10}{*}{ Siltstone/Sandstone } & KA30 1-1 & 99.93 & 45.38 & 37.67 \\
\hline & KA30 1-2 & 99.47 & 29.93 & 36.92 \\
\hline & КА30 2-1 & 104.34 & 58.10 & 45.48 \\
\hline & КА30 2-2 & 104.34 & 46.43 & 45.48 \\
\hline & КА30 3-1 & 99.39 & 34.02 & 36.79 \\
\hline & KA30 3-2 & 103.56 & 44.78 & 44.02 \\
\hline & КА30 4-1 & 103.30 & 36.60 & 43.53 \\
\hline & КА30 4-2 & 99.16 & 28.74 & 36.41 \\
\hline & KA30 4-3 & 99.07 & 35.41 & 36.27 \\
\hline & КА30 4-4 & 99.01 & 37.27 & 36.17 \\
\hline
\end{tabular}


Table A.2 (continued)

\begin{tabular}{|c|c|c|c|c|}
\hline & Sample ID & ASI & UCS (laboratory) & UCS (estimated) \\
\hline Rhyolitic lava & KAW 171 & 86.78 & 22.11 & 20.34 \\
\hline \multirow[t]{2}{*}{ Siltstone/Sandstone } & KAW17 3-2 & 97.82 & 32.91 & 34.31 \\
\hline & KAW 17 C2 4 & 65.83 & 11.10 & 6.09 \\
\hline Deep formations & NM1 1-2 & 114.19 & 80.86 & 67.44 \\
\hline \multirow[t]{32}{*}{ Rhyolitic ignimbrite } & NM1 1-1 & 125.14 & 114.29 & 100.58 \\
\hline & NM2 2-3 & 86.05 & 20.82 & 19.60 \\
\hline & NM2 2-1 & 90.02 & 30.95 & 23.87 \\
\hline & NM2 2-2 & 86.66 & 29.58 & 20.22 \\
\hline & NM $33-2$ & 82.06 & 22.73 & 15.94 \\
\hline & NM3 3-1 & 85.82 & 23.00 & 19.38 \\
\hline & NM3 3-3 & 80.75 & 22.87 & 14.85 \\
\hline & NM3 3-7 & 85.94 & 24.88 & 19.50 \\
\hline & NM3 3-4 & 81.01 & 16.03 & 15.06 \\
\hline & NM 4 & 100.03 & 35.29 & 37.84 \\
\hline & NM 4 & 90.67 & 22.55 & 24.64 \\
\hline & NM 5 5-2 & 102.94 & 62.11 & 42.88 \\
\hline & NM 5 5-1 & 103.56 & 39.41 & 44.02 \\
\hline & NM8A C1-1 & 107.02 & 51.67 & 50.81 \\
\hline & NM8A C1-2 & 107.80 & 62.31 & 52.44 \\
\hline & NM8A C1-3 & 112.03 & 65.59 & 62.05 \\
\hline & NM8A C1-5 & 121.76 & 100.49 & 89.27 \\
\hline & NM8A C1-6 & 106.97 & 53.90 & 50.71 \\
\hline & NM11 1-2 & 93.68 & 34.50 & 28.41 \\
\hline & NM11 1-3 & 93.60 & 35.32 & 28.30 \\
\hline & NM11 1-4 & 93.77 & 35.37 & 28.54 \\
\hline & NM11 1-5 & 93.80 & 33.04 & 28.57 \\
\hline & KA37 1-1 & 101.86 & 41.22 & 40.95 \\
\hline & KA37 1-2 & 101.80 & 39.36 & 40.84 \\
\hline & KA37 1-3 & 105.05 & 49.66 & 46.84 \\
\hline & KA37 1-4 & 105.02 & 43.75 & 46.79 \\
\hline & KA37 1-5 & 93.67 & 28.78 & 28.40 \\
\hline & KA37 1-6 & 101.77 & 36.29 & 40.80 \\
\hline & KA37 1-7 & 101.76 & 37.41 & 40.78 \\
\hline & KA37 1-8 & 101.90 & 34.65 & 41.03 \\
\hline & KA37 2-1 & 104.84 & 44.92 & 46.44 \\
\hline & KA37 2-2 & 105.77 & 55.47 & 48.28 \\
\hline \multirow[t]{29}{*}{ Andesite lava/breccia } & NM 7-1 & 144.17 & 130.24 & 186.60 \\
\hline & NM 7-2 & 146.38 & 188.08 & 199.46 \\
\hline & NM 7-3 & 143.82 & 135.26 & 184.66 \\
\hline & NM 7-4 & 137.83 & 106.99 & 153.34 \\
\hline & NM 7-5 & 116.08 & 36.72 & 72.46 \\
\hline & NM 7-6 & 142.41 & 123.02 & 176.87 \\
\hline & NM 7-7 & 134.34 & 113.13 & 137.10 \\
\hline & NM 7-8 & 111.24 & 23.92 & 60.16 \\
\hline & NM 7-9 & 140.74 & 174.40 & 167.98 \\
\hline & NM 7-10 & 126.35 & 127.10 & 104.89 \\
\hline & NM 7-11 & 138.77 & 160.83 & 157.99 \\
\hline & NM 7-12 & 117.15 & 36.60 & 75.40 \\
\hline & KA3 1-2 & 109.55 & 63.19 & 56.26 \\
\hline & KA3 2 & 109.40 & 71.37 & 55.93 \\
\hline & RK27L2_21 21.1 C & 111.30 & 69.53 & 60.29 \\
\hline & RK27L2_2121.8 B & 111.90 & 79.91 & 61.72 \\
\hline & RK27L2_2121.5 B & 113.36 & 85.99 & 65.33 \\
\hline & RK27L2_212 3.2 A & 129.40 & 105.26 & 116.43 \\
\hline & RK27L2_21 20.4 B & 136.05 & 211.05 & 144.87 \\
\hline & RK28_23 10.6 A & 129.32 & 92.07 & 116.09 \\
\hline & RK28_23 10.8C & 132.35 & 109.91 & 128.45 \\
\hline & RK28_23 10.9 C & 132.69 & 137.31 & 129.89 \\
\hline & RK28_23 13.2 A & 136.29 & 146.22 & 146.03 \\
\hline & RK28_23 10.6 C & 136.93 & 146.24 & 149.01 \\
\hline & RK30_23 21.0 A & 131.92 & 126.53 & 126.63 \\
\hline & RK30_23 22.3 B & 136.81 & 137.97 & 148.48 \\
\hline & RK30_23 22.4 A & 139.07 & 148.44 & 159.47 \\
\hline & RK30_23 21.1 B & 137.65 & 157.93 & 152.49 \\
\hline & RK30_23 21.7 B & 144.67 & 162.71 & 189.44 \\
\hline \multirow[t]{10}{*}{ Tonalite intrusive } & NM8-NM8A C2 1 & 131.01 & 123.14 & 122.88 \\
\hline & NM9 1-1 & 114.73 & 67.25 & 68.84 \\
\hline & NM9 1-2 & 120.28 & 81.72 & 84.62 \\
\hline & NM9 1-3 & 115.03 & 65.84 & 69.63 \\
\hline & NM9 1-4 & 121.72 & 84.27 & 89.12 \\
\hline & NM9 1-5 & 121.53 & 108.24 & 88.51 \\
\hline & NM9 1-6 & 123.29 & 83.47 & 94.24 \\
\hline & NM9 1-7 & 123.34 & 77.01 & 94.43 \\
\hline & NM9 1-8 & 115.26 & 65.56 & 70.23 \\
\hline & NM9 1-9 & 115.87 & 76.01 & 71.89 \\
\hline
\end{tabular}


Table A.2 (continued)

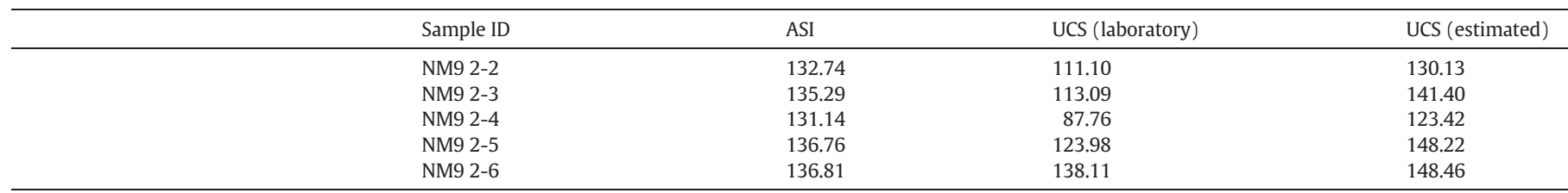

\section{References}

Ameen, M., Smart, B.G.D., Somerville, J.M., Hamilton, S., Naji, N.A., 2009. Predicting rock mechanical properties of carbonate from wireline logs (a case study: Arab-D reservoir, Ghawar field, Saudi Arabia). Mar. Pet. Geol. 4, 430-444.

ATSM International, 2010. D 7012-10 standard test method for compressive strength and elastic moduli of intact rock core specimens under varying states of stress and temperatures. Annual Book of ATSM Standards.

Baud, P., Zhu, W., Wong, T.F., 2000. Failure mode and weakening effect of water on sandstone. J. Geophys. Res. 105, 16371-16389.

Baud, P., Vinciguerra, S., David, C., Cavallo, A., Walker, E., Reuschle, T., 2009. Compaction and failure in high porosity carbondate: mechanical data and microstructural observations. Rock Phys. Nat. Hazards 869-898.

Begonha, A., Sequeira Braga, M.A., 2002. Weathering of the Oporta Granite; geotechnical and physical properties. Catena 49, 57-76.

Bibby, H.M., Caldwell, T.G., Davey, F.J., Webb, T.H., 1995. Geophysical evidence on the structure of the Taupo Volcanic Zone and its hydrothermal circulation. J. Volcanol. Geotherm. Res. 68, 29-58.

Bieniawski, Z.T., 1967. Mechanisms of brittle fracture of rock part II - experimental studies. Int. J. Rock Mech. Min. Sci. 4, 407-423.

Bieniawski, Z.T., Denkhaus, H.G., Vogler, U.W., 1969. Failure of fractured rock. Int. J. Rock Mech. Min. Sci. 6, 323-341.

Binal, A., 2009. Prediction of mechanical properties of non-welded and moderately welded ignimbrite using physical properties ultrasonic pulse velocity and point load index tests. Q. J. Eng. Geol. Hydrogeol. 42, 107-122.

Brantut, N., Heap, M.J., Meredith, P.G., Baud, P., 2013. Time-dependent cracking and brittle creep in crustal rocks: a review. J. Struct. Geol. 52, 17-43.

Broz, M.E., Cook, R.F., Whitney, D.L., 2006. Microhardness, toughness and modulus of Mohs scale minerals. Am. Mineral. 91, 135-142.

Ceryan, S., Tudes, S., Ceryan, N., 2008. A new quantitative weathering classification for igneous rocks. Environ. Geol. 6, 1319-1336.

Chang, C., Zoback, M.D., Khaksar, A., 2006. Empirical relations between rock strength and physical properties in sedimentary rock. J. Pet. Sci. Eng. 3-4, 223-237.

Çobanoğlu, I., Çelik, S.B., 2008. Estimation of uniaxial compressive strength from point load strength, Schmidt hardness and P-Wave velocity. Bull. Eng. Geol. Environ. 4, 491-498.

Coggan JS, Stead D, Howe JH, Faulks 2013. Mineralogical controls on the engineering behaviour of hydrothermally altered granites under uniaxial compression. Eng. Geol. 160:89-102.

Cole, J.W., 1990. Structural control and origin of the volcanism in the Taupo volcanic zone, New Zealand. Bull. Volcanol. 52, 445-459.

Cumming, W., 2009. Geothermal resource conceptual models using surface exploration data. Proceedings, Thirty-Fourth Workshop on Geothermal Reservoir Engineering. Stanford University, California.

Dinçer, I., Acar, A., Çobanoğlu, I., Uras, Y., 2004. Correlation between Schmidt hardness, uniaxial compressive strength and young's modulus for andesite, basalts and tuffs. Bull. Eng. Geol. Environ. 2, 141-148.

Dobson, P.F., Kneafsey, T.J., Hulen, J., Simmons, A., 2003. Porosity, permeability, and fluid flow in the Yellowstone geothermal system, Wyoming. J. Volcanol. Geotherm. Res. $123,313-324$.

Edlmann, K., Somerville, J.M., Smart, B.G.D., Hamilton, S.A., Crawford, B.R., 1998. Predicting rock mechanical properties from wireline porosities. Proceedings SPE/ISRM Eurock, Trondheim (Norway).

Entwisle, D., Hobbs, P., Jones, L., Gunn, D., Raines, M.G., 2005. The relationship between porosity, uniaxial compressive strength and sonic velocity of intact Borrowdale volcanic group core samples from Sellafield. Geotech. Geol. Eng. 23, 793-809.

Esmaeily, D., Afshooni, S.Z., Mirnejad, H., Rashidnejad-e-Omran, N., 2012. Mass changes during hydrothermal alteration associated with gold mineralization in the Astaneh granitoid rocks, Western Iran. Geochem. Explor. Environ. Anal. 12, 161-175.

Fakhimi, A., Gharahbagh, E.A., 2011. Discrete element analysis of the effect of pore size and pore distribution on the mechanical behaviour of rock. Int. J. Rock Mech. Min. Sci. 48, 77-85.

Ferry, J., 1979. Reaction mechanisms, physical conditions, and mass transfer during hydrothermal alteration of mica and feldspar in granitic rocks from south-central Maine, USA. Contrib. Mineral. Petrol. 139, 125-139.

Frolova, J., Ladygin, V., Franzson, H., Sigurdsson, O., Stefansson, V., Shustrov, V., 2005. Petrophysical properties of fresh to mildly altered hyaloclasitie tuffs. Proceedings World Geothermal Congress, Antalya (Turkey).

Frolova, J.V., Ladygin, V.M., Rychagov, S.N., 2010. Petrophysical alteration of volcanic rocks in hydrothermal systems of the Kuril-Kamchatka Island Arc. Proceedings, World Geothermal Congress. Bali, Indonesia 25-29 April 2010.
Giggenbach, W.F., 1984. Mass transfer in hydrothermal alteration systems - a conceptual approach. Geochim. Cosmochim. Acta 48, 2693-2711.

Goff, F., Janik, C.J., 2000. Geothermal systems. In: Sigurdsson, H. (Ed.), Encyclopedia of Volcanoes. Academic Press.

Gunsallus, K.L., Kulhawy, F.H., 1984. A comparative evaluation of rock strength measures. Int. J. Rock Mech. Min. Sci. Geomech. Abstr. 21, 233-248.

Heap, M.J., Lavallée, Y., Petrakova, L., Baud, P., Reuschlé, T., Varley, N.R., Dingwell, D.B. 2014a. Microstructural controls on the physical and mechanical properties of edifice-forming andesites at Volcan de Colima, Mexico. J. Geophys. Res. 1-39.

Heap, M.J., Xu, T., Chen, C.F., 2014b. The influence of porosity and vesicle size on the brittle strength of volcanic rocks and magma. Bull. Volcanol. 76, 1-15.

Heap, M.J., Kennedy, B.M., Pernin, N., Jacquernard, L., Baud, P., Farquharson, J.I., Scheu, B., Lavallee, Y., Gilg, H.A., Letham-Brake, M., Mayer, K., Jolly, A.D., Reuschle, T. Dingwell, D.B., 2015. Mechanical behaviour and failure modes in the Whakaari (White Island volcano) hydrothermal system, New Zealand. J. Volcanol. Geotherm. Res. 295, 26-42.

Henneberger, R.C., Browne, P.R.L., 1988. Hydrothermal alteration and evolution of the Ohakuri Hydrothermal system, Taupo Volcanic Zone, New Zealand. J. Volcanol. Geotherm. Res. 34, 211-231.

Hillier, S., 2000. Accurate quantitative analysis of clay and other minerals in sandstone by XRD: comparison of a Rietveld and a reference intensity ratio (RIR) method and the importance of sample preparation. Clay Miner. 35, 291-302.

Hudyma, N., Burçin Avar, B., Karakouzian, M., 2004. Compressive strength and failure modes of lithophysae-rich Topopah Spring Tuff specimens and analog models containing cavities. Eng. Geol. 73, 179-190.

Karakul, H., Ulusay, R., 2013. Empirical correlations for predicting strength properties of rock from p-wave velocity under different degrees of saturation. Rock Mech. Min. Sci. 5, 981-999.

Karfakis, M.G., 1985. Drilling mechanisms at elevated rock temperatures. Int. J. Rock Mech. Min. Sci. Abstr. 22, 407-417.

Kissling, W.M., Weir, G.J., 2005. The spatial distribution of the geothermal fields in the Taupo Volcanic Zone, New Zealand. J. Volcanol. Geotherm. Res. 145, 136-150.

Koncagül, E.C., Santi, P.M., 1999. Predicting the unconfined strength of the Breathitt shale using slake durability, shore hardness and rock structural properties. Int. J. Rock Mech. Min. Sci. 36, 139-153.

Kusznir, N.J., Park, R.G., 1987. The extensional strength of the continental lithosphere; its dependence on geothermal gradient, and crustal composition and thickness. Geol. Soc. Lond., Spec. Publ. 28, 35-52.

Ladygin, V., Frolova, J., Rychagov, S., 2000. Formation of composition and petrophysical properties of hydrothermally altered rocks in geothermal reservoir. Proceedings. World Geothermal Congress, Kyushu-Tokoku, Japan. May 28 June 10, 2000.

Lama, R.D., Vutukuri, V.S., 1978. Handbook on Mechanical Properties of Rocks. vol. 2. Editor Trans Tech Publications, Clausthal, Germany.

Li, L., Aubertin, M., 2003. A general relationship between porosity and uniaxial strength of engineering material. Can. J. Civ. Eng. 30, 644-658.

Li, Y., Wang, J., Jung, W., Ghassemi, A., 2012. Mechanical properties of intact rock and fractures in welded tuff from Newberry Volcano. Proceedings. Thirty-Seventh Workshop on Geothermal Reservoir Engineering, Stanford, California.

Luping, T., 1986. A study of the quantitative relationship between strength and pore size distribution of porous materials. Cem. Concr. Res. 16, 87-96.

Martin, C.D., 1997. Seventeenth Canadian geotechnical colloquium: the effect of cohesion loss and stress path on brittle rock strength. Can. Geotech. J. 34, 698-725.

Mueller, S., Melnik, O., Spieler, O., Scheu, B., Dingwell, D.B., 2005. Permeability and degassing of dome lavas undergoing rapid decompression: an experimental determination. Bull. Volcanol. 67, 526-538.

Nara, Y., Meredith, P.G., Yoneda, T., Kaneko, K., 2011. Influence of macro-fractures and micro-fractures on permeability and elastic wave velocities in basalt at elevated pressure. Tectonophysics 503, 52-59.

Palchik, V., 1999. Influence of porosity and elastic modulus on uniaxial compressive strength in soft brittle porous sandstone. Rock Mech. Rock. Eng. 32, 303-309.

Pola, A., Crosta, G., Fusi, N., Barberini, V., Norini, G., 2012. Influence of alteration on physical properties of volcanic rocks. Tectonophysics 566-567, 67-86.

Pola, A., Crosta, G.B., Fusi, N., Castellanza, R., 2014. General characterization of the mechanical behaviour of different volcanic rocks with respect to alteration. Eng. Geol. 169, 1-13.

Price, N.J., 1960. The compressive strength of coal measure rocks. Coll. Engl. 37, 283-292.

Rawal, C., Ghassemi, A., 2010. Reactive flow in a natural fracture in poro-thermo-elastic rocks. Proceedins: 35th Workshop on Geothermal Reserviour Engineering (Standford, Californa).

Reyes, A.G., 1990. Petrology of Philippine geothermal systems and the application of alteration mineralogy to their assessment. J. Volcanol. Geotherm. Res. 43, 279-309. 
Rigopoulos, I., Tsikouras, B., Pomonis, P., Hatzipanagiotou, K., 2010. The influence of alteration on the engineering properties of dolerites: the examples from the Pindos and Vourinos ophiolites (northern Greece). Rock Mech. Min. Sci. 47, 69-80.

Rowland, J.V., Sibson, R.H., 2004. Structural controls on hydrothermal flow in a segmented rift system, Taupo Volcanic Zone, New Zealand. Geofluids 4, 259-283.

Rowland, J.V., Simmons, S.F., 2012. Hydrologic, magmatic, and tectonic controls on hydrothermal flow, Taupo Volcanic Zone, New Zealand: implications for the formation of epithermal vein deposits. Econ. Geol. 107, 427-457.

Sammis, C.G., Ashby, M.F., 1986. The failure of brittle porous solids under compressive stress states. Acta Metall. 34, 511-526.

Shea, T., Houghton, B.F., Gurioli, L., Cashman, K.V., Hammer, J.E., Hobden, B.J., 2010. Textural studies of vesicles in volcanic rocks: an integrated methodology. J. Volcanol. Geotherm. Res. 190, 271-289.

Simmons, S.F., Browne, P.R.L., 2000. Hydrothermal minerals and precious metals in the Broadlands-Ohaaki Geothermal systems: implications for understanding lowsulfidation epithermal environments. Econ. Geol. 95, 971-999.

Singh, T.N., Kainthola, A., AV, 2012. Correlation between point load index and uniaxia compressive strength for different rock types. Rock Mech. Rock. Eng. 2, 259-264.

Siratovich, P.A., Heap, M.J., Villenueve, M.C., Cole, J.W., Reuschle, T., 2014. Physical property relationship of the Rotokawa Andesite, a significant geothermal reservoir rock in the Taupo Volcanic Zone, New Zealand. Geotherm. Energy Sci. 2, 1-31.

Smith, R., Sammonds, P.R., Kilburn, C.R.J., 2009. Fracturing of volcanic systems: experimental insights into pre-eruptive conditions. Earth Planet. Sci. Lett. 1-4, 211-219.

Sousa, L.M.O., Suarez del Rio, L.M., Calleja, L., Ruiz de Argandona, R., Rodriguez Rey, A. 2005. Influence of microfractures and porosity on the physic-mechanical properties and weathering of ornamental granites. Eng. Geol. 77, 153-168.

Stringham, B., 1952. Fields of formation of some common hydrothermal alteration minerals. Soc. Econ. Geol. 47, 661-664.

Tamrakar, N., Yokota, S., Sherestha, S., 2007. Relationship among mechanical, physical and petrological properties of Siwalik sandstones, Central Nepal Sub-Himalayas. Eng. Geol. 3-4, 105-123.

Tuğrul, A., Zarif, I.H., 1999. Correlation of mineralogical and textural characteristics with engineering properties of selected granitic rocks from Turkey. Eng. Geol. 51, 303-317.

Ulusay, R., Tureli, K., Ider, M.H., 1994. Prediction of engineering properties of a selected litharenite sandstone from its petrographic characteristics using correlation and multivariate statistical techniques. Eng. Geol. 37, 135-157.

Ulusay, R., Hudson, J.A., 2007a. Standard method for determining water content, porosity, density, absorption and related properties. The Complete ISRM Suggested Methods for Rock Characterization, Testing and Monitoring: 1974-2006. Turkish National Group, pp. 85-92 (1978).

Ulusay, R., Hudson, J.A., 2007b. Standard method for determining the uniaxial compressive strength and deformability of rock materials. The Complete ISRM Suggested Methods for Rock Characterization, Testing and Monitoring: 1974-2006. Turkish National Group, pp. 121-132 (1979).

Villeneuve, M.C., Diederichs, M.S., Kaiser, P.K., 2012. Effects of grain scale heterogeneity on rock strength and the chipping process. Int. J. Geomech. 12, 632-647.

Vinciquerra, S., Trovato, C., Meredith, P.G., Benson, P.M., 2005. Relating seismic velocities, thermal cracking and permeability in Mt. Etna and Iceland basalts. Int. J. Rock Mech. Min. Sci. 7-8, 900-910

Vutukuri, V.S., Lama, R.D., Saluja, S.S., 1974. Handbook on Mechanical Properties of Rock. vol. 1. Editor Trans Tech Publications, Clausthal, Germany.

Walsh, J., 1961. The effects of cracks on the compressibility of rocks. J. Geophys. Res. 70, 381-389.

Wangen, M., Munz, I.A., 2004. Formation of quartz veins by local dissolution and transport of silica. Chem. Geol. 209, 179-192.

Weinberg, R.B., Podladchikov, Y., 1994. Diapiric ascent of magmas through power law crust and mantle. J. Geophys. Res. 99, 9543-9559.

Whitney, D.L., Broz, M., Cook, R.F., 2007. Hardness, toughness and modulus of some common metamorphic minerals. Am. Mineral. 92, 281-288.

Wilson, C.J.N., Houghton, B.F. McWilliam, M.O, Lanphere, M.A., Weaver, S.D., Briggs, R.M. 1995. Volcanic and structural evolution of Taupo Volcanic Zone, New Zealand: a review. J. Volcanol. Geotherm. Res. 68, 1-28.

Wyering, L.D., Villeneuve, M.C., Wallis, I.C., 2012. The effects of hydrothermal alteration on the physical and mechanical rock properties of the Andesite Breccia and Tahorakuri Formation from the Ngatamariki Geothermal field, New Zealand and empirical relations between rock strength and physical properties. Proceedings, New Zealand Geothermal Workshop, Auckland (New Zealand).

Wyering, L.D., Villeneuve, M.C., Wallis, I.C., Siratovich, P.A., Kennedy, B.M., Gravley, D.M., Cant, J.L., 2014. Mechanical and physical properties of hydrothermally altered rocks, Taupo Volcanic Zone, New Zealand. J. Volcanol. Geotherm. Res. 188, 76-93.

Yagiz, S., 2009. Predicting uniaxial compressive strength, modulus of elasticity and index properties of rocks using the Schmidt hammer. Bull. Eng. Geol. Environ. 68, 55-63.

Yıldız, A., Kusccu, M., Dumlupunar, I., Krrem Aritan, A., Begci, M., 2010. The determination of the mineralogical alteration index and the investigation of the efficiency of the hydrothermal alteration on physic-mechanical properties in volcanic rocks from Koprulu, Afyonkarahisar, West Turkey. Bull. Eng. Geol. Environ. 69, 51-61. 